DOE/RL-96-93

Rev. 0

\title{
Engineering Evaluation/ Cost Analysis for the 233-S Plutonium Concentration Facility
}

Date Published

January 1997

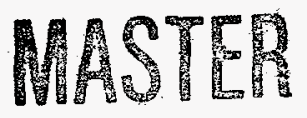

United States

Department of Energy

P.O. Box 550

Richland, Washington 99352

DISTRIBUTION OF THIS DOCUMENT IS UNLIMTTED 


\section{DISCLAIMER}

This report was prepared as an account of work sponsored by an agency of the United States Government. Neither the United States Government nor any agency thereof, nor any of their employees, makes any warranty, express or implied, or assumes any legal liability or responsibility for the accuracy, completeness, or usefulness of any information, apparatus, product, or process disclosed, or represents that its use would not infringe privately owned rights. Reference berein to any specific commercial product, process, or service by trade name, trademark, manufacturer, or otherwise does not necessarily constitute or imply its endorsement, recommendation, or favoring by the United States Government or any agency thereof. The views and opinions of authors expressed herein do not necessarily state or reflect those of the United States Government or any agency thereof. 


\section{DISCLAIMER}

Portions of this document may be illegible electronic image products. Images are produced from the best available original document. 
DOE/RL-96-93

Rev. 0

\section{CONTENTS}

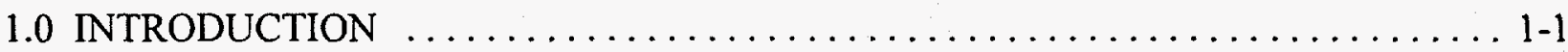

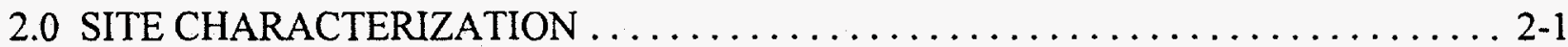

2.1 BACKGROUND AND SITE DESCRIPTION $\ldots \ldots \ldots \ldots \ldots \ldots \ldots \ldots .2-1$

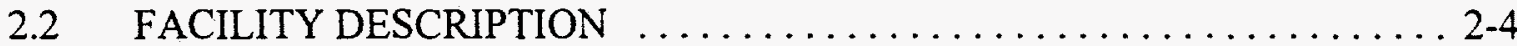

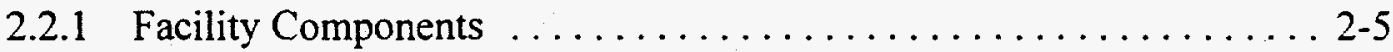

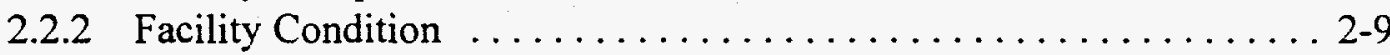

2.3 SOURCE, NATURE, AND EXTENT OF CONTAMINATION ....... 2-11

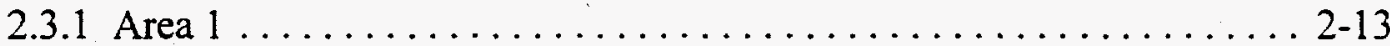

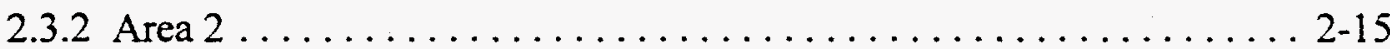

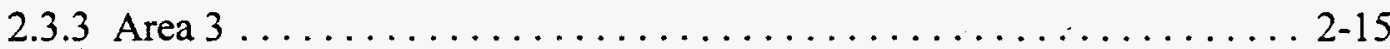

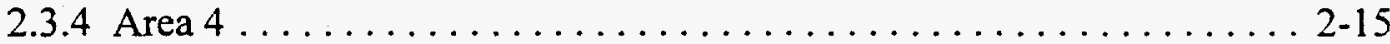

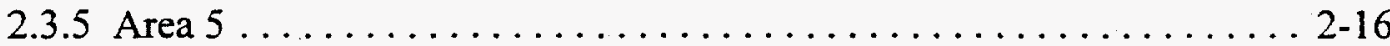

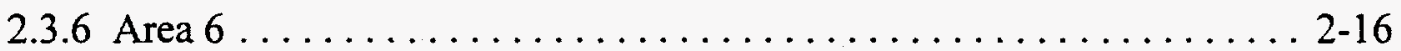

2.4 SITE CONDITIONS THAT JUSTIFY A REMOVAL ACTION ......... 2-16

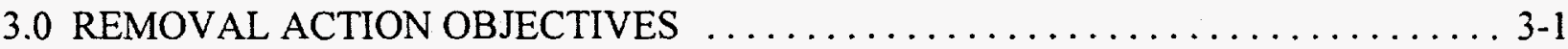

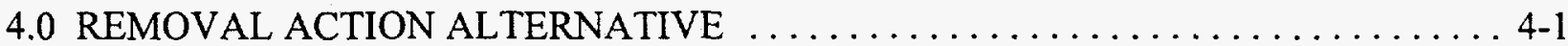

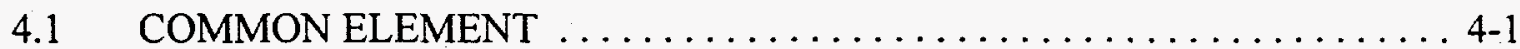

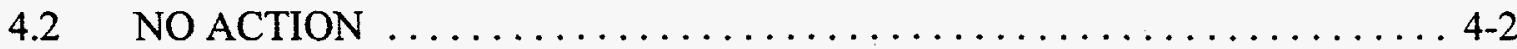

4.3 CONTINUED SURVEILLANCE AND MAINTENANCE $\ldots \ldots \ldots \ldots \ldots 4-3$

4.4 DECONTAMINATION WITH REDUCED SURVEILLANCE

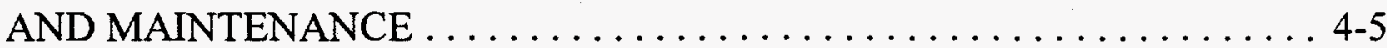

4.5 DECONTAMINATION AND DEMOLITION $\ldots \ldots \ldots \ldots \ldots \ldots \ldots .4-6$

5.0 COMPARATIVE ANALYSIS OF ALTERNATIVES $\ldots \ldots \ldots \ldots \ldots \ldots \ldots \ldots \ldots$. 1

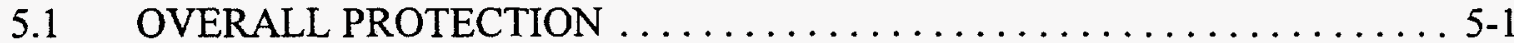

5.2 COMPLIANCE WITH APPLICABLE OR RELEVANT AND APPROPRIATE REQUIREMENTS AND OTHER STANDARDS $\ldots \ldots \ldots 5-2$

5.2 .1 Waste Management Standards .................... 5-2

5.2.2 Air Emission Control Standards . . . . . . . . . . . . . . . . 5-3

5.2.3 Cultural and Ecological Resource Protection Standards ........ 5-4

5.2.4 Radiation Protection Standards . . . . . . . . . . . . . . . . 5

5.2 .5 Polychlorinated Biphenyls . . . . . . . . . . . . . . . . . . . .

5.2 .6 Asbestos . . . . . . . . . . . . . . . . . . . . . . . . . 5-5

5.3 LONG-TERM EFFECTIVENESS $\ldots \ldots \ldots \ldots \ldots \ldots \ldots \ldots \ldots \ldots .7$

5.4 REDUCTION OF TOXICITY, MOBILITY, OR VOLUME $\ldots \ldots \ldots \ldots \ldots .5-8$

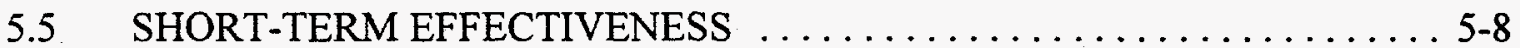

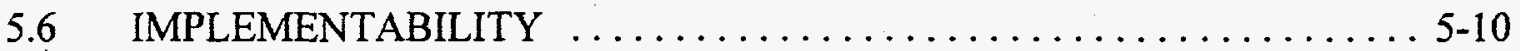

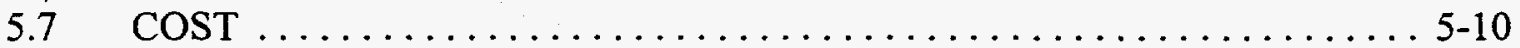


DOE/RL-96-93

Rev. 0

CONTENTS (continued)

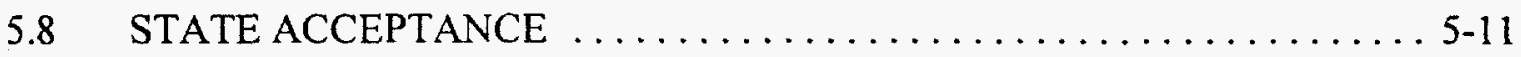

5.9 COMMUNITY ACCEPTANCE $\ldots \ldots \ldots \ldots \ldots \ldots \ldots \ldots \ldots \ldots \ldots ., 5-11$

5.10 OTHER CONSIDERATIONS $\ldots \ldots \ldots \ldots \ldots \ldots \ldots \ldots \ldots \ldots \ldots ., 5-11$

6.0 RECOMMENDED REMOVAL ACTION ALTERNATIVE $\ldots \ldots \ldots \ldots \ldots \ldots .6-1$

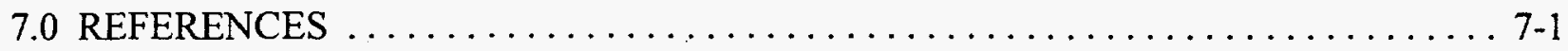

\section{FIGURES}

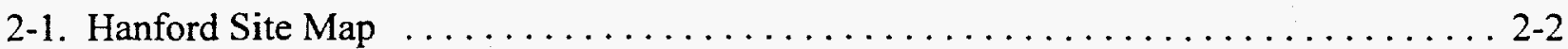

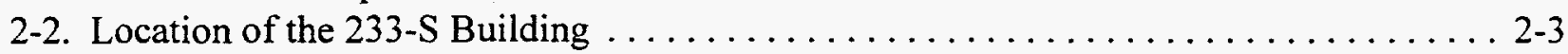

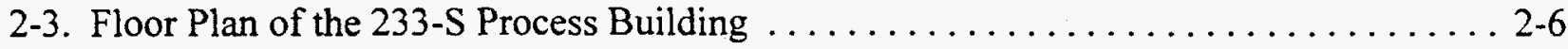

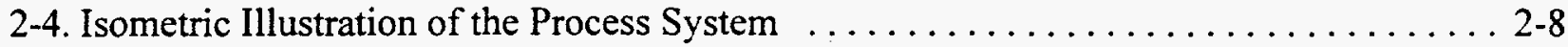

\section{TABLES}

2-1. Isotopic Composition of the Contamination in the 233-S Process Hood $2-12$

2-2. Nature and Extent of Potential Hazardous Substance Contamination in

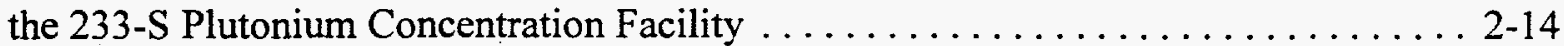

4-1. Cost Estimates: Continued Surveillance and Maintenance. ............... 4-4

4-2. Cost and Schedule Estimates: Decontamination with Reduced Surveillance and Maintenance. ............................... 4 4

4-3. Cost and Schedule Estimates: Decontamination, Demolition, and Disposal ....... 4-8 


\section{ACRONYMS}

$\begin{array}{ll}\text { ARAR } & \text { applicable or relevant and appropriate requirements } \\ \text { BHI } & \text { Bechtel Hanford, Inc. } \\ \text { CERCLA } & \text { Comprehensive Environmental Response. Compensation, and Liability Act of } \\ & \text { 1980 } \\ \text { cfm } & \text { cubic feet per minute } \\ \text { CFR } & \text { Code of Federal Regulations } \\ \text { D\&D } & \text { decontamination and decommissioning } \\ \text { DOE } & \text { U.S. Department of Energy } \\ \text { dpm } & \text { disintegrations per minute } \\ \text { Ecology } & \text { Washington State Department of Ecology } \\ \text { EE/CA } & \text { Engineering Evaluation/Cost Analysis } \\ \text { ERDF } & \text { Environmental Restoration Disposal Facility } \\ \text { EPA } & \text { U.S. Environmental Protection Agency } \\ \text { HEPA } & \text { high-efficiency particulate air } \\ \text { LATA } & \text { Los Alamos Technical Associates } \\ \text { LLW } & \text { low-level waste } \\ \text { MEI } & \text { maximally exposed individual } \\ \text { NDA } & \text { nondestructive assay } \\ \text { NEPA } & \text { National Environmental Policy Act } \\ \text { OSHA } & \text { Occupational Safety and Health Administration } \\ \text { PCB } & \text { polychlorinated biphenyl } \\ \text { PR } & \text { plutonium removal } \\ \text { RC } & \text { unloading recycle } \\ \text { RCRA } & \text { Resource Conservation and Recovery Act of 1976 } \\ \text { REDOX } & \text { Reduction-Oxidation (Plant) } \\ \text { RL } & \text { U.S. Department of Energy, Richland Operations Office } \\ \text { TSCA } & \text { Toxic Substances Control Act of 1976 } \\ \text { SHPO } & \text { State of Washington Historic Preservation Office } \\ \text { S\&M } & \text { surveillance and maintenance } \\ \text { SWP } & \text { special work permit } \\ \text { TRU } & \text { transuranic } \\ \text { WAC } & \text { Washington Administrative Code } \\ \text { WHC } & \text { Westinghouse Hanford Company } \\ \end{array}$


DOE/RL-96-93

Rev. 0 
DOE/RL-96-93

Rev. 0

\subsection{INTRODUCTION}

The 100, 200, 300 and 1100 Areas of the Hanford Site were placed on the U.S. Environmental Protection Agency's (EPA) National Priorities List in November 1989 under the Comprehensive Environmental Response, Compensation, and Liability Act of 1980 (CERCLA). The deactivated 233-S Plutonium Concentration Facility (233-S Facility) is located in the 200 Area. The facility has undergone severe degradation due to exposure to extreme weather conditions. A rapid freeze and thaw cycle occurred at the Hanford Site during February 1996, which caused cracking to occur on portions of the building's roof. This has resulted in significant infiltration of water into the facility, which provides a pathway for potential release of radioactive material into the environment (air and/or ground). The weather caused several existing cracks in the concrete portions of the structure to lengthen, increasing the potential for failed confinement of the radioactive material in the building. Differential settlement has also occurred, causing portions of the facility to separate from the main building structure thus creating a potential for release of radioactive material to the environment. An expedited removal action ${ }^{2}$ is proposed to ensure that a release from the 233-S Facility does not occur.

The U.S. Department of Energy (DOE), Richland Operations Office (RL), in cooperation with the EPA, has prepared this Engineering Evaluation/Cost Analysis (EE/CA) pursuant to CERCLA. Based on the evaluation, RL has determined that hazardous substances ${ }^{1}$ in the $233-\mathrm{S}$ Facility may present a potential threat to human health and/or the environment, and that an expedited removal action ${ }^{2}$ is warranted. Due to initiation of the single regulator concept at the Hanford Site, EPA has been designated as the lead regulatory agency. Comments will be provided by the State of Washington Department of Ecology (Ecology) during the public comment period. The purpose of the EE/CA is to provide the framework for the evaluation and selection of a technology from a viable set of alternatives for a removal action. The EPA and RL will prepare and sign an action memorandum documenting the alternative chosen following public review of the EE/CA. The EE/CA was prepared in accordance with the requirements of CERCLA and 40 Code of Federal Regulations (CFR) 300.415 and is intended to aid in selecting a preferred removal action alternative.

This EE/CA is also part of the environmental restoration initiative pilot project that was created to develop a method for demonstrating compliance with DOE orders through implementation of the CERCLA process. The environmental restoration initiative pilot-project participants (comprising DOE Headquarters, RL, EPA, and Ecology) jointly agreed that the EE/CA

\footnotetext{
"Hazardous substances" as used in this document means those substances defined by Section 101(14) of CERCLA.

2"Remove" or "removal," as defined by Section 101(23) of CERCLA, refers to the cleanup or removal of released hazardous substances from the environment; actions taken in the event of a threat of release of hazardous substances; actions to monitor, assess, and evaluate the release (or threat of release) of hazardous substances; the disposal of removed material; or other actions that may be necessary to prevent, minimize, or mitigate damage to public health or welfare or to the environment, which may otherwise result from a release or threat of release.
} 
DOE/RL-96-93

Rev. 0

represents the first of two documents prepared to establish an authorization basis for conducting decommissioning activities at the 233-S Facility. The removal action design report is the final document used to obtain such authorization. The pilot project team established this method to streamline administrative safety requirements to provide more cost efficient and timely

processing. 
DOE/RL-96-93

Rev. 0

\subsection{SITE CHARACTERIZATION}

\subsection{BACKGROUND AND SITE DESCRIPTION}

The Hanford Site is located in south-central Washington State (Figure 2-1) and was selected as the nation's first large-scale nuclear materials production site in January 1943. Plutonium was produced by irradiating uranium fuel elements using reactors located in the 100 Area of the Hanford Site. After the fuel was irradiated, it was taken to separations plants located in the 200 Area, where the cladding was removed from the fuel elements and the plutonium was extracted. The Reduction-Oxidation (REDOX) Plant was brought on line in January 1952. The REDOX Plant was the world's first nuclear solvent extraction plant using the reduction-oxidation process and operated through July 1967 . The 233-S Facility was built in 1955 to expand production and further concentrate the plutonium nitrate product solution from the REDOX Plant. The 233-S

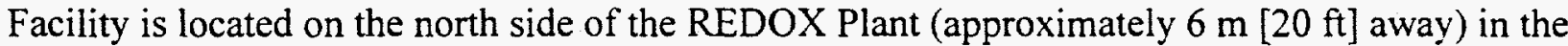
200 West Area of the Hanford Site, as shown in Figures 2-1 and 2-2.

Public access to the Hanford Site beyond the Wye Barricade, including the 200 Area, is currently restricted. Current land use in the 200 Area consists of DOE waste management and cleanup activities. Future land use of the 200 Area has not been determined; however, the draft document, The Future for Hanford: Uses and Cleanup (DOE-EPS 1992), proposes that the 200 Area be designated for industrial use.

The plant community within the perimeter of the 200 Area is characterized primarily as sagebrush/cheatgrass or Sandberg's bluegrass communities. These plant communities contain numerous plant and animal species adapted to the semiarid environments. No plants or animals on the Federal or state list of endangered and threatened wildlife and plants are found in the vicinity of the 233-S Facility. Further information on ecological resources in the 200 Area and threatened, endangered, and candidate species at the Hanford Site is available in Cushing (1995). There are no perennial or ephemeral streams in the $200 \mathrm{Area}$, and there are no regulated wetlands within the 200 West Area.

Although the Hanford Site contains numerous well-preserved archaeological sites representing both the prehistoric and historical periods, there are no identified archaeological sites or artifacts in the vicinity of the 233-S Facility (Chatters and Cadoret 1990). The closest identified site is the White Bluffs Road, which crosses diagonally (southwest to northeast) through the northern portion of the 200 West Area. The road, formerly an Indian trail, has been in use since antiquity and played a role in early immigration, development, and agriculture. 
DOE/RL-96-93

Rev. 0

Figure 2-1. Hanford Site Map.

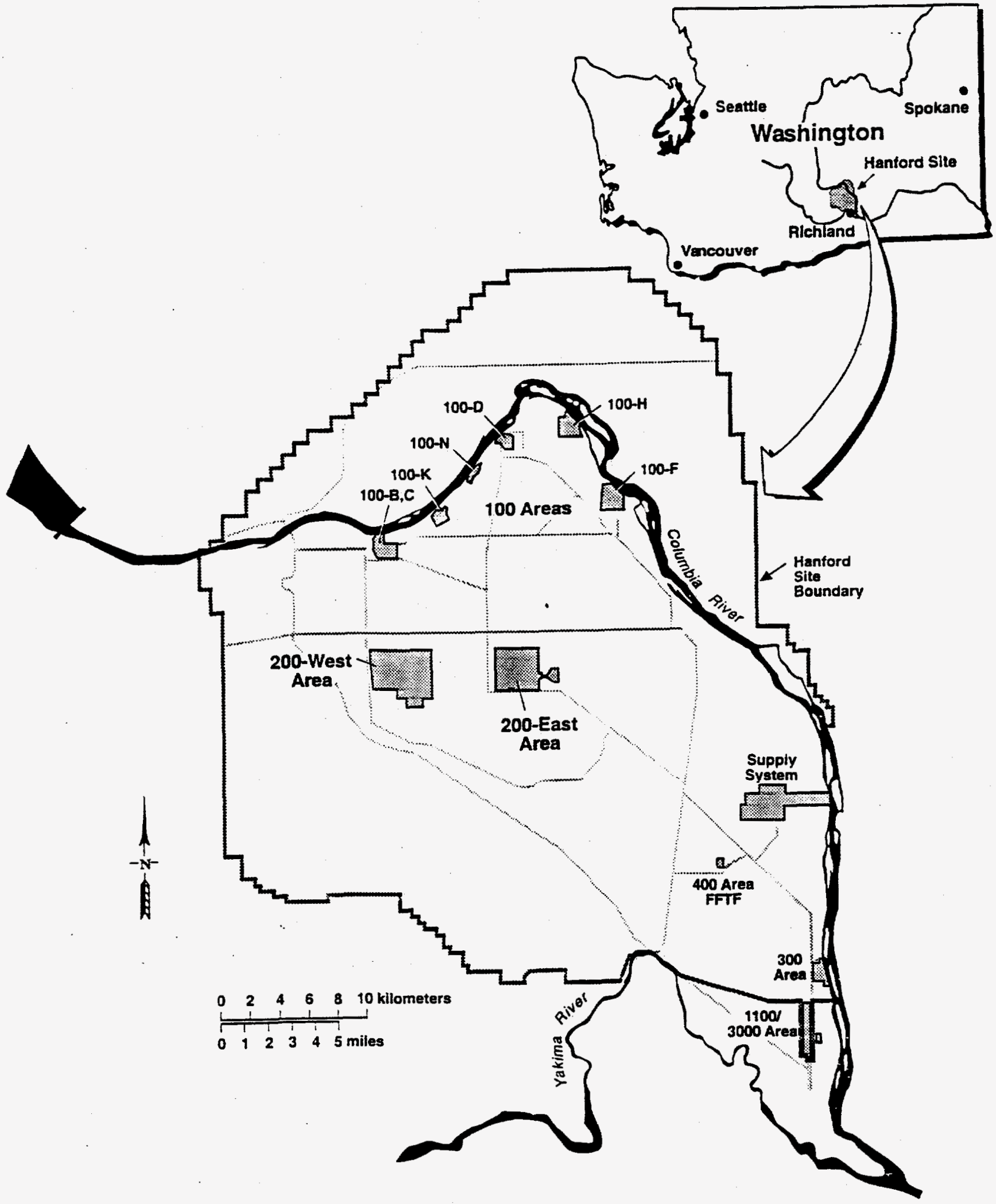


DOE/RL-96-93

Rev. 0

Figure 2-2. Location of the 233-S Building.

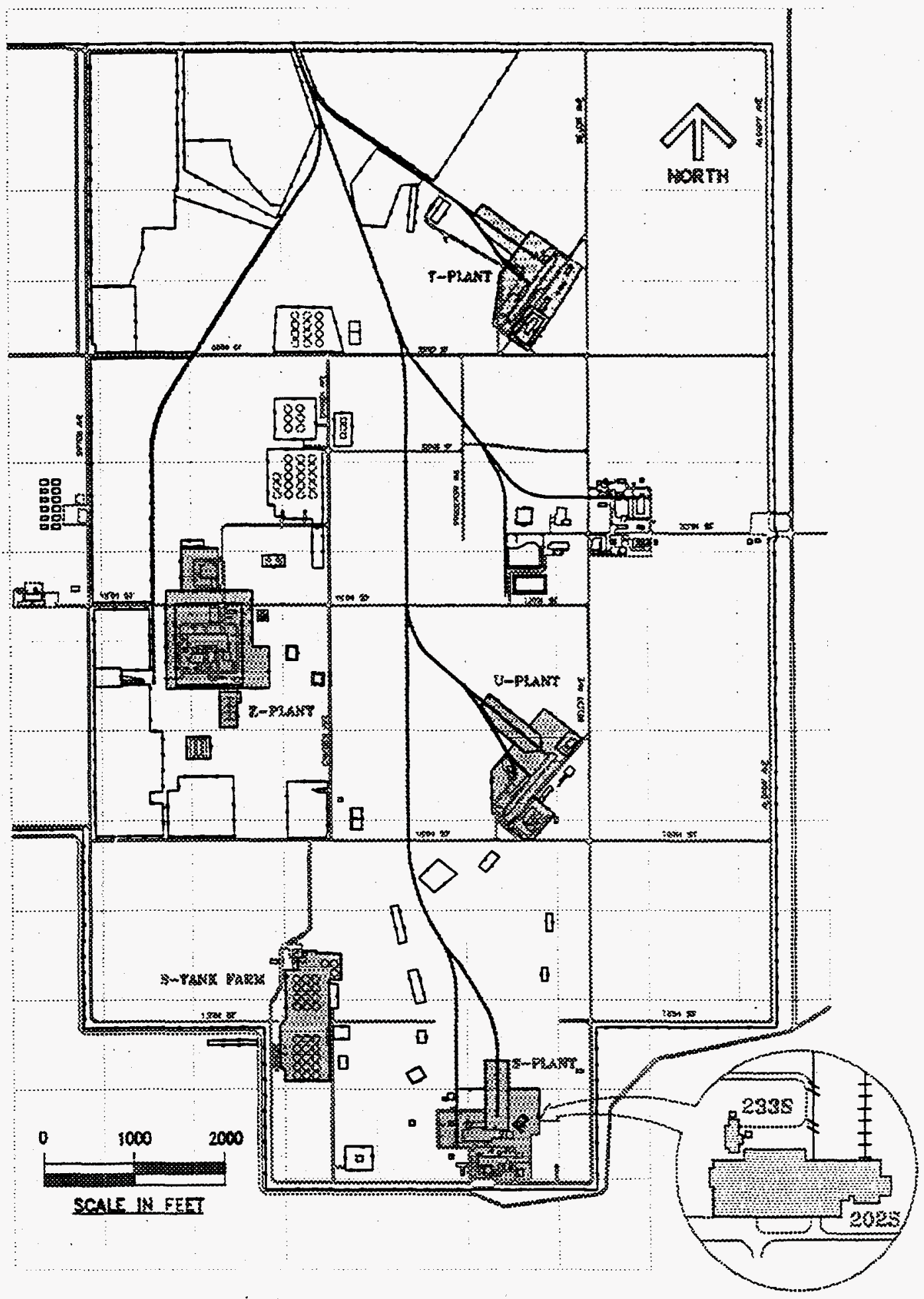


The State of Washington Historic Preservation Office (SHPO) determined that the 233-S Facility has potential historical significance. The SHPO stated that although the 233-S Facility is not considered to be individually eligible for listing on the National Register of Historic Places. the 233-S Facility does appear to merit consideration as a contributing element to a potential historic district centered on the adjacent REDOX Plant, as both plants were closely connected not only in location but also in operation (Griffith 1994). A memorandum of agreement is in place between the SHPO, DOE, and the Advisory Council on Historic Preservation. The memorandum of agreement identifies the requirements to document the history of the facility in accordance with guidance provided by the Historical Architectural Building Survey requirements. Since the 233S Facility is considered potentially historically significant by the SHPO, the required documentation (Historic American Engineering Record WA-129-A) was prepared and submitted to the National Park Service. Upon receipt of the documentation package, the National Park Service archived the package in the Library of Congress, thus allowing the dismantlement of the 233-S Facility to proceed, if such an alternative is selected.

\section{$2.2 \quad$ FACILITY DESCRIPTION}

The 233-S Plutonium Concentration Facility is composed of the original 233-S Process Building, additions/modifications thereto, the 233-SA Exhaust Filter Building, and interconnecting piping, trenches, and ducting. The 233-S Building was modified by expansion in 1958. This expansion included the addition of maintenance platforms in the process cell viewing room with an exterior stairwell and airlocks for entry, an additional plutonium removal (PR) can room, and a spare exhauster. Modifications in 1962 included the installation of an anion exchange purification process in the process hood, the conversion of one plutonium concentrator for neptunium use and other vessel modifications, and numerous piping modifications. The 233-SA Exhaust Filter Building was added in 1964 after a process upset that resulted in a fire (see Section 2.2.2).

In 1967, the 233-S Building was shut down and placed in a layaway status. Some of the tasks that were performed during the layaway of the 233-S Building include the following:

- Process equipment and vessels were internally flushed for product removal.

- The equipment inside the process and load-out hoods was externally flushed, and the interior of the loads was decontaminated to remove gross contamination (equipment in the load-out hood was removed in 1979).

- Combustibles, tools, supplies, and unneeded portable equipment were removed.

- Loose paint was removed and bare spots were repainted.

- Internal walls and floors were cleaned to levels of smearable contamination to the extent practicable. 
- $\quad$ Some surface contamination was fixed beneath applications of paint.

- $\quad$ Air sampler valves were closed.

- $\quad$ Some doors were sealed and entry doors were locked.

Decontamination and decommissioning (D\&D) activities were performed on approximately $25 \%$ of the facility during fiscal years 1979 and 1980. Further D\&D work was scheduled for FY 1981 but was deferred because of budget constraints. Further stabilization and modification of the facility were performed in December 1987 (WHC 1988) to remove loose surface contamination from the rooms and spaces adjacent to the process hood (excluding the process hood and pipe gallery). Activities that occurred in December 1987 include the following:

- Ventilation system repair and modification

- $\quad$ Outside area decontamination and stabilization

- Interior decontamination and stabilization

- Final radiological survey.

\subsubsection{Facility Components}

2.2.1.1 233-S Process Building. The 233-S Process Building is a reinforced concrete structure $11.3 \mathrm{~m}(37 \mathrm{ft})$ by $25.7 \mathrm{~m}(86 \mathrm{ft})$, with $20.3-\mathrm{cm}(8$-in.) thick walls and 15.2-cm (6-in.) thick floors and ceilings. The newer portions of the process building are constructed of metal and structural steel (see Section 2.2.1.11). The building includes the main contaminated areas, primarily where process-related activities had taken place, and nonprocess areas where contamination is expected to be significantly less. The main contaminated areas consist of the process hood, pipe trench, stairwell and two airlocks, viewing room, and PR can load-out room. The nonprocess areas consist of two can storage rooms, a pipe gallery, control room, equipment room, special work permit (SWP) change room, lavatory, an abandoned filter box, and three airlocks, as seen in the floor plan presented in Figure 2-3. Each of the five airlocks are approximately $9 \mathrm{~m}^{2}$ and were added to the facility after operations identified need for additional contamination control. The southwest airlock is made of concrete blocks, while the other four airlocks are metal additions.

2.2.1.2 233-S Process Cell. The process cell is a four-story-high bay with $30.5-\mathrm{cm}$ (12-in.) thick concrete walls, and the cell is divided into two zones. The two zones contained within the process cell, the process hood and the viewing room, are separated with a partition of transparent panels and structural steel. The transparent panels have previously been covered with an opaque paint for contamination control purposes. 
DOE/RL-96-93

Rev. 0

Figure 2-3. Floor Plan of the 233-S Process Building.

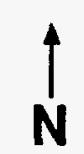
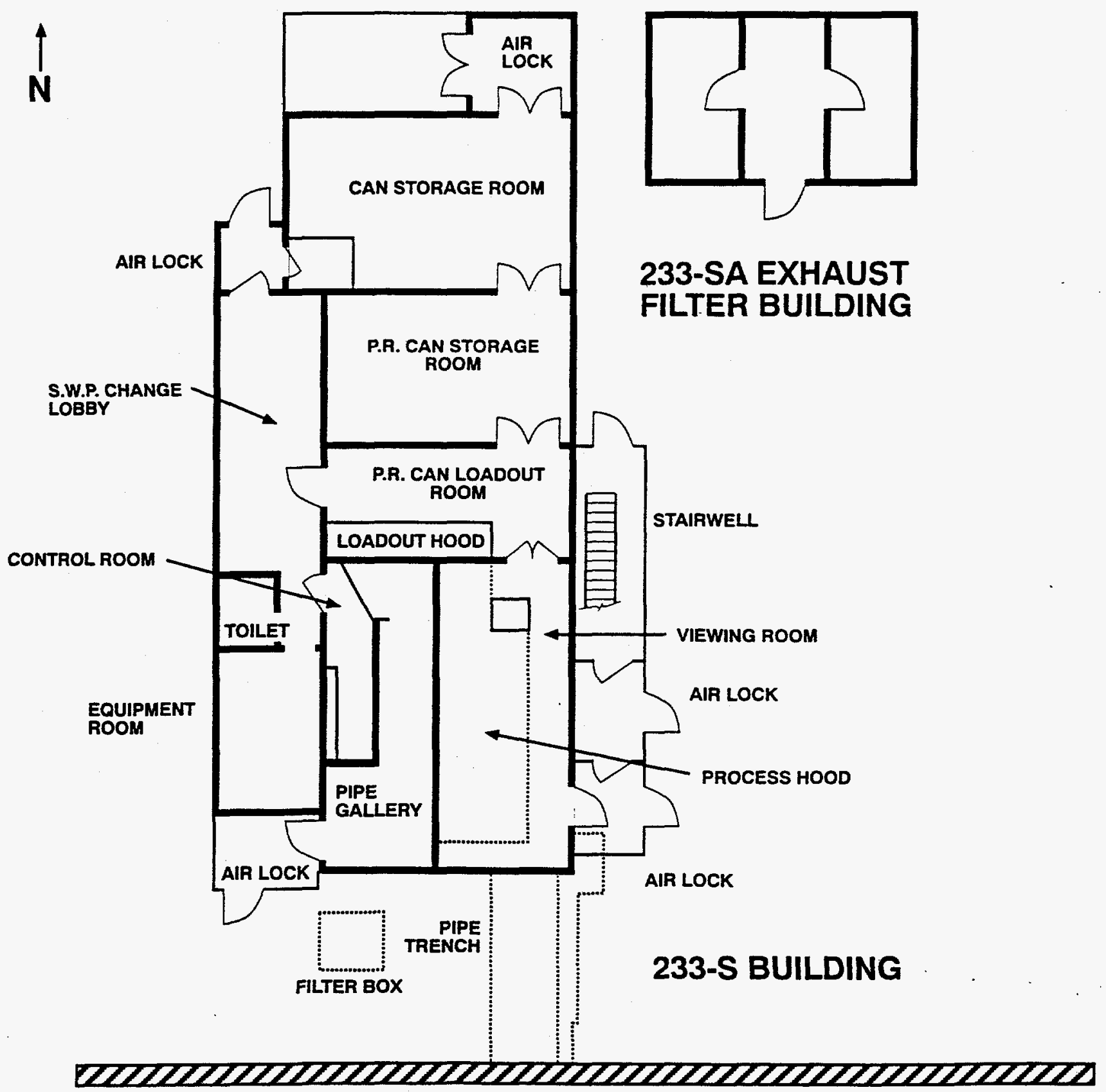

202-S BUILDING 


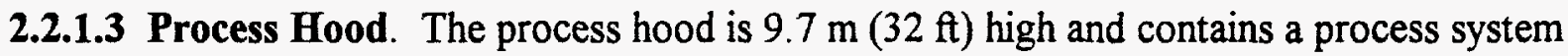
array with criticality-safe process vessels up to $7 \mathrm{~m}(23 \mathrm{ft})$ tall and $17.8 \mathrm{~cm}(7$ in) inside diameter. Plutonium nitrate solution was pumped from the REDOX E-3 Feed Tank to the 233-S L-12 Feed Tank. The solution was concentrated by boiling and/or ion exchange treatment and loaded into PR cans in the load-out hood prior to shipment for final work at the 231-Z Plutonium Isolation Building or the 234-5Z Plutonium Finishing Plant. An isometric illustration of the process system is presented in Figure 2-4.

2.2.1.4 Viewing Room. The viewing room provides access to each of the three upper levels of the process cell via three open-grating walkways along the east and south sides of the process hood enclosure. The original access ladder remains in the southwest corner. The walkways are located such that they divide the height of the viewing room into approximately equal segments of $2.4 \mathrm{~m}(8 \mathrm{ft})$. At the north end of the viewing room, the wall at the upper level of the hood supports electric and process instrumentation equipment.

2.2.1.5 PR Can Load-Out. The PR can load-out and decontamination room is located on the north side of the process hood. The load-out hood is located on the south side, or on the common wall with the process hood, and is a confinement type work station that was used for loading PR cans with concentrated plutonium nitrate solution, neptunium solutions, and unloading recycle (RC) cans for rework in 233-S or 202-S. Decontamination of the PR and RC cans was also performed in the load-out hood. The stairwell and southeast airlocks associated with this area became contaminated during process hood operations.

2.2.1.6 Process Pipe Trench. The pipe trench is a 7-m, $15.2-\mathrm{cm}$ (23-ft, 6-in.) long concrete subgrade structure running between the REDOX Building and the southeast corner of the 233-S Building. The pipe trench is divided into two parallel sections to separate radiological solution transfer lines and nonradiological piping. The concrete cover blocks have metal plates concealing recessed lifting bails. A neptunium pipe trench with metal covers was added in the 1962 upgrade and is located adjacent to the pipe trench. The pipe trench structure and all contained piping are within the scope of this EE/CA.

2.2.1.7 Nonprocess Areas. The can storage rooms allowed $68 \mathrm{PR}$ and $\mathrm{RC}$ cans to be stored while awaiting shipment or recycle back into the system. These rooms are on the north side of the load-out room. The equipment room contains the necessary equipment, ducting, and wiring required to provide and control makeup air to the building. Much of the ducting is insulated with asbestos materials. Airborne contamination may have deposited on equipment surfaces during upset operation conditions. 


$$
\begin{gathered}
\text { DOE/RL-96-93 } \\
\text { Rev. } 0
\end{gathered}
$$

Figure 2-4. Isometric Illustration of the Process System.

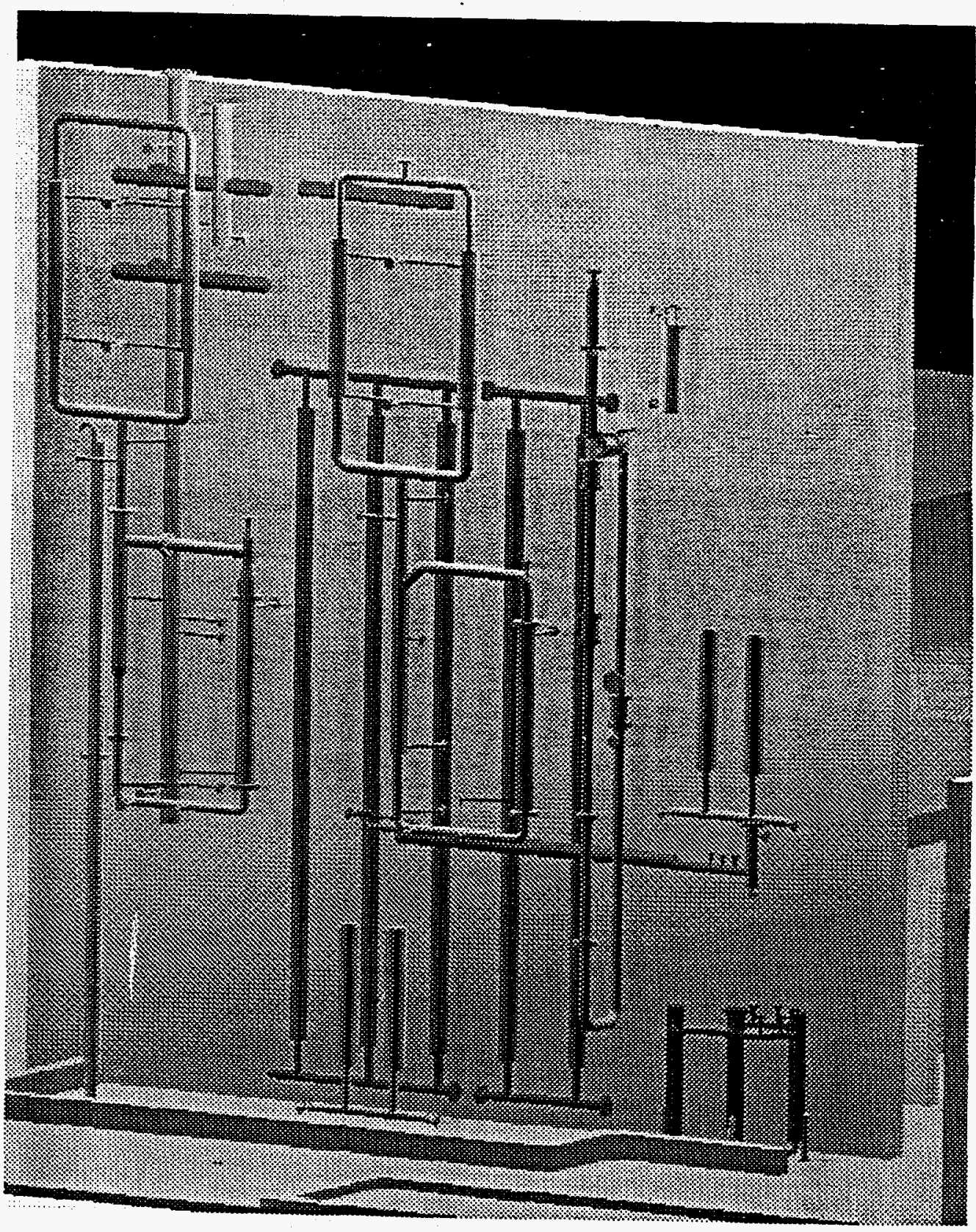


2.2.1.8 Nonprocess Pipe Gallery and Control Room. The pipe gallery contains nonprocess support lines from the REDOX Building that enter the area through the viewing room. Equipment in the room includes instrument lines. steam lines, a chemical makeup tank and a variety of control panels. The control panels are separated from the process area by plastic panels that create an isolated control room. The interior of the nonprocess lines is not expected to be radiologically contaminated.

2.2.1.9 Abandoned Filter Box. The abandoned filter box is a reinforced concrete structure located below grade, between the REDOX Building and the 233-S Facility. The filter box is approximately $1.8 \mathrm{~m}(6 \mathrm{ft})$ wide by $1.8 \mathrm{~m}(6 \mathrm{ft})$ deep by $3.65 \mathrm{~m}(12 \mathrm{ft})$ long, with $15.2-\mathrm{cm}(6-\mathrm{in})$ thick walls and was used as a backup system during the time of the 1963 fire. The primary system was the original filtration system for the facility. A temporary filtration unit was installed to allow the existing chemical warfare service filters to be replaced. With the tie-in of the 233-SA Building, the unneeded ductwork and aboveground filters were removed, and the filter box was abandoned. It is unknown if the chemical warfare service filters were abandoned in place.

2.2.1.10 233-SA Exhaust Filter Building. The 233-SA Exhaust Filter Building was constructed following the 1963 fire to handle the exhaust ventilation for the 233-S Plutonium Concentration Facility. The 233-SA Filter Building is a one-story, $4.9 \mathrm{~m}(16 \mathrm{ft})$ by $7.3 \mathrm{~m}(24 \mathrm{ft})$ reinforced concrete structure with $15.2 \mathrm{~cm}$ (6 in.) walls. The filter building is located on a $7.3 \mathrm{~m}(24 \mathrm{ft})$ square, $20.3-\mathrm{cm}(8$-in.) thick reinforced concrete pad at the northeast corner of the 233-S Process Building. The filter building contains two parallel filter banks. Each bank has a prefilter and a series of double high-efficiency particulate air (HEPA) filters with its own exhaust fan, 7.6-m (25-ft) high metal stack, and sampling equipment. The fans and stacks are located to the north of the building and are designated 296-S-7 East and 296-S-7 West.

2.2.1.11 233-S and 233-SA Facility Roofs. The roofs of the original 233-S Process Building and the 233-SA Filter Building (those building sections constructed with concrete walls) are 15.2-cm (6-in.) -thick concrete. The newer sections of the 233-S Process Building (constructed with metal walls affixed to structural steel frames) are roofed with metal plate. The roofs include the base structural materials (metal or concrete) with a layer of insulation covered with tarred gravel. The roofs support the exhaust ventilation ducting and various arrays of electrical conduct and facility system pipes. Various locations on the roofs that have become radioactively contaminated from past upset conditions have been coated with foam and sealants to confine contaminants. The facility roofs have currently been declared sufficiently sound to support minor on-roof repair operations to temporarily seal cracks and prevent further in-facility water leakage.

\subsubsection{Facility Condition}

A chemical fire in 1963 severely damaged the anion exchange concentrator in the process hood, and the anion exchange purification process was abandoned without equipment removal. Following an intensive six-week cleanup of the facility surroundings and roof, the residual 
contamination was fixed with paint and the 233-S Facility was restarted and operated until deactivation in 1967. This deactivation process included flushing the process system with nitric acid (with rinse solution sent back to REDOX), decontamination of contaminated surfaces, and the application of fixatives. This building has been addressed by DOE's Surplus Facility Management Program since 1967 as a retired facility.

Decontamination and demolition of the 233-S Facility was selected in 1978 as a demonstration project. A major effort began to decontaminate and decommission this facility but stopped in 1981 due to lack of funding. This activity accomplished initial characterization and housekeeping of the facility and removed the contents and equipment in the load-out hood. The contamination within the load-out hood was stabilized, and plexiglass panels equipped with HEPA filters were installed to cover the openings. Subsequently, the interior of the load-out hood was recontaminated with plutonium nitrate by migration through the previously sealed wall penetrations from the adjoining process hood. The hood contains a sump that is covered with a dry cracked substance.

Stabilization activities on interior and exterior areas of the facility were completed in 1987. This work sealed both the 202-S REDOX column laydown trench and the pipe trench between the 233-S Facility and the REDOX Plant. The activities also fixed contamination around these trenches and the north wall of the REDOX Plant with an asphalt emulsion and accomplished decontamination and fixative application inside the 233-S Facility.

In 1990, radiological and chemical characterization surveys were accomplished and reported in Radiological Characterization of the 233-S Facility (WHC 1990a) and 233-S Facility Potential Chemical Hazards (WHC 1990b). Other work accomplished in 1990 included the application of fixatives on the deteriorating roof to fix contamination that was resurfacing from the 1963 fire. Additional work was started in 1992 to decontaminate several areas that were recontaminated due to plutonium migration. Plutonium can be a very mobile radionuclide, and ongoing decontamination efforts are required to control the spread of contamination.

The facility water and nonprocess steam lines have been disconnected, the floor drains have been filled with grout, and the electrical utilities have been deactivated. Temporary construction power has been installed to maintain fire alarms, ventilation fans, lighting, and temporary heating. One non-valved, $1.9 \mathrm{~cm}(0.75 \mathrm{in}$.) water line is still active inside the SWP change room of the 233-S Building. In concert with these efforts, an extensive cleanup of trash, loose contamination coverings, furniture, portable equipment, and various supplies has been performed. Approximately 2,000 $\mathrm{ft}^{3}$ of low-level waste (LLW) was generated in these activities that has been appropriately disposed of onsite. On surfaces where loose contamination coverings were removed, new fixatives were applied to confine the contamination. Additionally, an airlock was installed on the door to the viewing room (i.e., in the PR can room), and filters were appropriately placed between facility areas to control contamination migration that can result from the directional air flow within the building. 
The structural integrity of the facility is degrading due to severe weather, water infiltration, and the lack of facility heat. The roof loading capacity has been downgraded. In addition, visual inspection shows the stairwell slab to be settling, allowing the steel-enclosed stairwell to pull away from the viewing room. Aside from the facility cleanup operations described above, only repair of the leaking facility roof has been planned and scheduled. This effort is only to seal the roof locations where in-flow of precipitation occurs. At this point of effort, no other activities for facility stabilization are planned, and only response to upset conditions that may result from the continuing building deterioration will be implemented. The near-term startup of this facility $D \& D$ project is expected to resolve any unstable conditions.

\subsection{SOURCE, NATURE, AND EXTENT OF CONTAMINATION}

The 233-S Facility is contaminated with hazardous substances used in or generated by plutonium concentration operations. Most of the hazardous substances are radioactive materials that contaminated the interior of the 233-S Facility. Fissile material inventories are also known to exist. The major inventory of fissile material is contained within the vessels of the process hood, but some fissile contamination is found throughout most of the facility. Current radiation survey data indicate that fixed contamination exists in all rooms and on the roof. Smearable plutonium (alpha) and minor mixed fission products (beta/gamma) contamination exists in the process hood, viewing room, PR can load-out room, stairwell, stairwell airlocks, and pipe gallery. Radiological samples taken to support emission estimates (DOE-RL 1994), and nondestructive assay (NDA) was performed to quantify the more significant fissile inventories in the process hood (SEG 1995). A criticality evaluation was performed to assess the potential of a criticality accident due to the fissile inventories and the proposed removal actions (BHI 1996a).

This evaluation, conducted by Los Alamos Technical Associates, Inc. (LATA), demonstrated that individually, each of the process vessels is subcritical. Calculations performed by Bechtel Hanford, Inc. (BHI) confirm this finding, assuming optimum moderation of the fissile material within the vessel and full water reflection conditions. The LATA criticality evaluation also demonstrated that the array of process vessels is subcritical. Again, LATA's evaluation was confirmed by BHI calculations using conservative assumptions that the fissile material within the vessels is optimally moderated and that the array is reflected on all sides by concrete. Finally, BHI calculations analyzed several off-normal and accident conditions, including a factor of two measurement error for the fissile material in the vessel with the largest inventory and the release of the contents of all the vessels during removal. For all cases analyzed, sufficient criticality safety margins were maintained.

Radiological surveys have been performed to determine the isotopic composition and distribution of radiological contamination. Isotopic analyses from samples taken during the surveys have identified the radioactive contaminants as ${ }^{237} \mathrm{~Np},{ }^{238} \mathrm{Pu},{ }^{239} \mathrm{Pu},{ }^{240} \mathrm{Pu},{ }^{241} \mathrm{Pu},{ }^{242} \mathrm{Pu},{ }^{241} \mathrm{Am}$, and their daughter products. Radiological surveys were performed in 1990 and 1994 to document the nature and extent of this contamination (WHC 1990a; SEG 1995). The 1990 report estimated that approximately $1,500 \mathrm{~g}( \pm 20 \%)$ of plutonium is present in and around the building. 
To better estimate the radionuclide inventory within the process hood, additional surveys were conducted in 1994 (SEG 1995). Isotopic analyses were performed on samples taken from materials originating inside process lines. The latter, more focused NDA survey confirmed that the 233-S Facility's process hood contains approximately $1,610 \mathrm{~g}$ of residual plutonium product, nearly all of it believed to be solidified in piping and vessels. Table 2-1 summarizes the isotopic composition and source term for both smearable and solidified contaminants based on information obtained during these surveys.

The removable (smearable) contamination present in the process hood is less than $4 \mathrm{~g}$. Air samples indicated no activity during a three-week test of the 9,000 cubic feet per minute (cfm) airflow from the hood, and based upon these results, the exhaust stack was downgraded to a minor stack ${ }^{1}$. The solidified source term in Table $2-1$ of approximately $1,610 \mathrm{~g}$ is based on the latest neutron assay with current half-life corrections, and includes the contribution of neptunium and americium from sample analyses.

Table 2-1. Isotopic Composition of the Contamination in the 233-S Process Hood.

\begin{tabular}{|c|c|c|c|c|c|}
\hline \multirow{2}{*}{ Radionuclide } & $\begin{array}{c}\text { Isotopic } \\
\text { Composition of } \\
\text { Radioactive } \\
\text { Material (Ci/g) } \\
\text { of Mixed } \\
\text { Isotopes }\end{array}$ & \multicolumn{2}{|c|}{$\begin{array}{c}\text { Source Term for Smearable } \\
\text { Material }\end{array}$} & \multicolumn{2}{c|}{$\begin{array}{c}\text { Source Term for Solidified } \\
\text { Material }\end{array}$} \\
\cline { 3 - 6 } & $\mathbf{C i}$ & $\mathbf{g}$ & $\mathbf{C i}$ & $\mathbf{g}$ \\
\hline${ }^{237} \mathrm{~Np}$ & $2.74 \mathrm{E}-05$ & $7.80 \mathrm{E}-05$ & $1.11 \mathrm{E}-01$ & $4.45 \mathrm{E}-02$ & $6.31 \mathrm{E}+01$ \\
\hline${ }^{238} \mathrm{Pu}$ & $7.63 \mathrm{E}-03$ & $2.11 \mathrm{E}-02$ & $1.23 \mathrm{E}-03$ & $1.21 \mathrm{E}+01$ & $7.04 \mathrm{E}-01$ \\
\hline${ }^{239} \mathrm{Pu}$ & $5.32 \mathrm{E}-02$ & $1.51 \mathrm{E}-01$ & $2.44 \mathrm{E}+00$ & $8.64 \mathrm{E}+01$ & $1.39 \mathrm{E}+03$ \\
\hline${ }^{240} \mathrm{Pu}$ & $1.81 \mathrm{E}-02$ & $5.09 \mathrm{E}-02$ & $2.24 \mathrm{E}-01$ & $2.91 \mathrm{E}+01$ & $1.28 \mathrm{E}+02$ \\
\hline${ }^{241} \mathrm{Pu}$ & $3.64 \mathrm{E}-01$ & $9.40 \mathrm{E}-01$ & $9.08 \mathrm{E}-03$ & $5.37 \mathrm{E}+02$ & $5.19 \mathrm{E}+00$ \\
\hline${ }^{244} \mathrm{Pu}$ & $1.32 \mathrm{E}-05$ & $3.73 \mathrm{E}-05$ & $9.48 \mathrm{E}-03$ & $2.13 \mathrm{E}-02$ & $5.42 \mathrm{E}+00$ \\
\hline${ }^{241} \mathrm{Am}$ & $2.44 \mathrm{E}-02$ & $9.96 \mathrm{E}-02$ & $2.91 \mathrm{E}-02$ & $5.69 \mathrm{E}+01$ & $1.67 \mathrm{E}+01$ \\
\hline Total & N/A & 1.3 & 2.8 & 721.1 & 1610 \\
\hline
\end{tabular}

The document 233-S Facility Potential Chemical Hazards (WHC 1990b) was generated to identify chemicals that were historically used in the 233-S Facility. However, it was emphasized that the chemicals historically used did not represent the inventory in the building at the time of the report preparation. All identified quantities of concentrated hazardous chemicals have been removed from the 233-S Facility during prior cleanup operations, although there may be some residual liquid in the process lines. Chemicals such as acetylene tetrabromide, hexone, nitric acid, sodium nitrate, and various coatings and caulking compounds are known to have been used in the 233-S Facility while the facility was operating; however, since deactivation, these

\footnotetext{
'A "minor stack" under 40 CFR 61.93 does not have the potential to discharge radionuclides to the air in excess of $0.1 \mathrm{mrem} / \mathrm{yr}$ effective dose to the public and does not require continuous emission monitoring. Monitoring requirements for a "minor stack" are periodic confirmation measurements, as specified in 40 CFR 61.93 .
} 
substances have not been found to exist in the building in more than very minor quantities. The building is expected to contain one or more of the hazardous materials that are present in most buildings at the Hanford Site. These materials include the following:

- $\quad$ Polychlorinated biphenyl (PCB) light ballast and non-PCB light ballast

- Lead paint

- $\quad$ Lead for shielding

- Mercury switches

- Fluorescent light bulbs

- Mercury or sodium vapor lights

- Used oil from motors and pumps.

The hazards associated with these materials are minor because they are contained within enclosed equipment with minimal likelihood for release.

There are asbestos-containing materials in the roof and walls of the building and on piping and ducts. Generally, these asbestos-containing materials are in a nonfriable form. Minor isolated areas of friable material are within airborne radiation areas.

A summary of the anticipated extent and nature of this contamination is provided in Table 2-2, and a detailed evaluation of hazards is provided in the safety analysis report (BHI 1996b). For the purpose of hazard evaluation, the 233-S Facility has been grouped into six areas based on a graduated state of radiological hazard. Area 1 represents the highest radiological hazard, and Area 6 presents the least hazard. Table 2-2 also presents building-wide conditions that may be encountered in any of the six areas of the 233-S Facility. The hazard evaluation is based on historical documents, such as the Westinghouse Hanford Company (WHC) radiological characterization report (WHC 1990a).

\subsubsection{Area 1}

Area 1 comprises the process hood only and represents the highest magnitude of hazards posed by the 233-S Facility. The process hood contains the highest radioactive contamination, with up to 25 million disintegrations per minute (dpm) smearable contamination estimated by extrapolating an open window ion chamber contact reading of $25 \mathrm{rad} / \mathrm{hr}$ from a sample obtained from the process hood. Beta-gamma contamination of up to $715 \mathrm{mr} / \mathrm{hr}$ on contact exists on the floor of the process hood from a ${ }^{137} \mathrm{Cs}$ source or resins spilled from the process tanks. The surface areas of the process hood are contaminated with alpha particles and beta-gamma contamination. This area is suspected to be a likely source of relatively high concentrations of airborne contamination. Prior to the entry of workers into this area, mitigation measures will be required to fix or otherwise stabilize the surface contamination to appropriate protective levels.

Nuclear concerns within Area 1 are associated with the fissile material inventory contained within the process system. These concerns have been addressed in the criticality evaluation previously discussed. 
DOE/RL-96-93

Rev. 0

Table 2-2. Nature and Extent of Potential Hazardous Substance Contamination in the 233-S Plutonium Concentration Facility. (Page 1 of 2)

\begin{tabular}{|c|c|}
\hline Area & Hazardous Substance \\
\hline $\begin{array}{l}\text { Process Hood } \\
\text { AREA } 1\end{array}$ & $\begin{array}{l}\text { - Radioactive contamination (airborne) } \\
\text {-Highest of two samples indicate around } 25 \text { million dpm fixed and } \\
\text { smearable alpha (alpha dose rate is approximately } 25 \mathrm{rad} / \mathrm{hr} \text { ) } \\
\text {-Less than } 4.0 \mathrm{~g} \text { is estimated to be smearable alpha. } \\
\text { - One } 715 \mathrm{mr} / \mathrm{hr} \text { survey indicates a maximum expected beta/gamma dose of } \\
1 \mathrm{R} / \mathrm{hr} \text { to extremities and } 500 \mathrm{mR} / \mathrm{hr} \text { to whole body. } \\
\text { - Plutonium nitrate liquids (potential) } \\
\text { - Lead paint } \\
\text { - Lead shielding (potential) } \\
\text { - Friable asbestos }\end{array}$ \\
\hline $\begin{array}{l}\text { (Process Cell) Viewing Room, } \\
\text { Stairwell, Stairwell Airlocks } \\
\text { AREA } 2\end{array}$ & $\begin{array}{l}\text { - Radioactive contamination (airbome) } \\
\text {-Swipes indicate up to } 420.000 \mathrm{dpm} \text { fixed and smearable alpha } \\
\text { - Highest transient air sample is } 300 \text { derived air concentration } \\
\text { - Lead paint } \\
\text { - Friable asbestos }\end{array}$ \\
\hline $\begin{array}{l}\text { Pipe Trench } \\
\text { AREA } 2\end{array}$ & - Radioactive contamination (inaccessible area; surveys not available) \\
\hline $\begin{array}{l}\text { PR Can Load-Out Room } \\
\text { AREA } 3\end{array}$ & $\begin{array}{l}\text { - Radioactive contamination } \\
\text {-Samples indicate up to } 490,000 \mathrm{dpm} \text { fixed and smearable alpha } \\
\text {-Smearable levels are negligible for dispersion } \\
\text { - Lead paint } \\
\text { - Nitric acid and sodium nitrate liquids (potential) } \\
\text { - Friable asbestos }\end{array}$ \\
\hline $\begin{array}{l}\text { Pipe Gallery and Control Room } \\
\text { AREA } 4\end{array}$ & $\begin{array}{l}\text { - Radioactive contamination } \\
\text { - Survey indicates up to } 1 \text { million dpm fixed direct alpha } \\
\text { - } 30,000 \mathrm{dpm} \text { smearable alpha } \\
\text { - } 0.01 \mathrm{~g} \text { estimated total smearable } \\
\text { - Lead paint } \\
\text { - Nitric acid and sodium nitrate liquids (potential) } \\
\text { - Asbestos }\end{array}$ \\
\hline $\begin{array}{l}\text { 233-SA Exhaust Filter Building } \\
\text { AREA } 5\end{array}$ & $\begin{array}{l}\text { - Radioactive contamination in filter banks is less than detectable } \\
\text { - Lead paint } \\
\text { - Asbestos }\end{array}$ \\
\hline $\begin{array}{l}\text { Abandoned Filter Box } \\
\text { AREA } 5\end{array}$ & $\begin{array}{l}\text { - Radioactive contamination ( inaccessible area, surveys not available) } \\
\text { - Lead paint } \\
\text { - Asbestos }\end{array}$ \\
\hline $\begin{array}{l}\text { Nonprocess Areas } \\
\text { (can storage rooms, equipment room, } \\
\text { SWP change room, lavatory, airlocks) } \\
\text { AREA } 6\end{array}$ & $\begin{array}{l}\text { - Radioactive contamination } \\
\text { - Survey indicates fixed contamination } \\
\text { - } 0.7 \mathrm{~g} \text { estimated total smearable } \\
\text { - Lead paint } \\
\text { - Asbestos in equipment room }\end{array}$ \\
\hline
\end{tabular}


DOE/RL-96-93

Rev. 0

Table 2-2. Nature and Extent of Potential Hazardous Substance Contamination in the 233-S Plutonium Concentration Facility. (Page 2 of 2)

\begin{tabular}{|l|l|}
\hline \multicolumn{1}{|c|}{ Area } & \multicolumn{1}{c|}{ Hazardous Substance } \\
\hline Building-wide & - Lead paint \\
& - Radioactive contamination \\
& - Asbestos \\
& Potential for nitric acid in process area \\
& - Potential for sodium nitrate in process area \\
& - Potential for ion exchange resins \\
& Potential for light ballasts and electrical controls to contain PCB \\
& - Potential for thermostats to contain mercury. \\
\hline
\end{tabular}

Nonradioactive contamination present in the process hood includes friable asbestos and lead paint. These nonradioactive contaminants represent a potential airborne threat to workers, but the threat is minor in comparison to the alpha contamination. Plutonium nitrate liquids may be contained in the L-16 plutonium recycle tanks; however, release potential is minimal due to the integrity of the tanks. If an alternative requiring disposal of waste is chosen for the removal action, lead and other heavy metals, asbestos, and liquids may require treatment prior to disposal.

\subsubsection{Area 2}

Area 2 includes the process cell viewing room, stairwell, stairwell airlocks, and the pipe trench. Friable asbestos and lead paint exist throughout Area 2. Area 2 contains up to $420,000 \mathrm{dpm}$ smearable alpha in the viewing room, presenting a potential for radionuclides to become airborne during decontamination activities. Radioactive liquids may also be present in subsurface viewing room piping. Smearable contamination also exists in the stairwell and stairwell airlocks. In the pipe trench, the level of contamination is unknown, but it is assumed that the hazards presented are similar to the rest of Area 2. Precautionary methods will be taken to identify potential hazards in the pipe trench through lessons learned in other piping systems in Area 2.

\subsubsection{Area 3}

This area comprises the PR can load-out hood room. Area 3 contains contamination levels of up to $490,000 \mathrm{dpm}$ alpha smearable, which is contributing to the slow spread of contamination throughout the facility. The same airborne hazards associated with Areas 1 and 2 exist in Area 3, however, the magnitude of the threat is much lower in Area 3. Small quantities of potentially airborne alpha contamination may exist on internal portions of the hood. Hazards presented by the nonradioactive contaminants in Area 1 are similar to Area 3.

\subsubsection{Area 4}

Area 4 includes the pipe gallery and control room. Friable asbestos and lead-based paint exist throughout Area 4. The pipe gallery contains high levels ( 1 million $\mathrm{dpm}$ ) of fixed alpha 
contamination, which presents a low hazard to workers because it is not mobile. Smearable alpha contamination levels of $30,000 \mathrm{dpm}$ have been found to exist internally in some of the piping systems. Smearable contamination presents more of a hazard than the fixed alpha due to the greater potential for radionuclides to become airbome. There may be some liquids remaining in the piping systems and the L-1 A chemical makeup tank. The liquids may contain corrosive or toxic levels of nitric acid and sodium nitrate.

\subsubsection{Area 5}

Area 5 consists of the 233-SA Filter Building and the abandoned filter box. Area 5 contains fixed radioactive contamination, lead-based paint, and asbestos, which present minimal hazards to workers.

\subsubsection{Area 6}

This area consists of all the other nonprocess areas including the can storage rooms, equipment room, SWP change room, lavatory, and airlocks. Low radioactive contamination exists in these areas. Lead and nonfriable asbestos are also present but present minimal hazards to workers.

\subsection{SITE CONDITIONS THAT JUSTIFY A REMOVAL ACTION}

The 233-S Facility has been in a continual state of slow deterioration since its deactivation in 1967, but routine maintenance has thus far been adequate to prevent environmental releases. Although D\&D has been initiated several times in the past, budget constraints caused deferral of permanent solutions. Ongoing maintenance efforts are becoming increasingly costly and are not totally responsive to the advancing deterioration process, thereby ranking this facility as an urgent priority for decommissioning. In addition, severe weather during the winter of 1995/1996 has accelerated the deterioration such that the facility represents a current potential for radiological release to the environment.

As the 233-S Facility ages, it will be more difficult to maintain radioactive material confinement. The surveillance and maintenance ( $\& \& M$ ) activities required to maintain confinement of the building will increasingly pose a potential exposure to personnel assigned to the activity. The potential exposure to personnel and the potential threat of a release justify a removal action. 
DOE/RL-96-93

Rev. 0

\subsection{REMOVAL ACTION OBJECTIVES}

Removal action objectives to protect human health and the environment include the following:

- $\quad$ Reduce the threat of release of hazardous substances contained in the 233-S Facility

- $\quad$ Protect workers from physical, chemical, and radiological hazards posed by the 233-S Facility

- Achieve project life cycle cost effectiveness by reducing or eliminating S\&M costs by reducing or eliminating the potential for a release of hazardous substances to the environment

- Attain applicable or relevant and appropriate requirements (ARAR) to the fullest extent practicable

- $\quad$ Minimize waste disposal costs

- Facilitate and be consistent with future remediation for the 200 Area.

The scope of this removal action is limited to the 233-S Facility, as described in Section 2.2. The principal threats to be addressed are radioactive materials and contaminated surfaces in the 233-S Facility. 


\section{DOE/RL-96-93}

Rev. 0 


\subsection{REMOVAL ACTION ALTERNATIVE}

Based on the removal action objectives, four alternatives have been identified in addition to the no-action alternative:

- Containment by grout injection

- $\quad$ Continued S\&M

- Decontamination and/or stabilization of hazardous substances with reduced S\&M

- Decontamination and/or stabilization of hazardous substances and demolition of the facility.

The containment alternative would consist of placing grout inside the facility (filling the room spaces and systems), installing vadose zone (dry hole) monitoring holes, and installing an earthen cap on top of the grouted monolith. This alternative has been screened out and will not be evaluated in detail for the following reasons: this technology has never been applied as a response action for permanent containment of transuranic (TRU) levels of radionuclides in an aboveground structure, and there has been no opportunity for significant evaluation of the potential effectiveness of the technology or of the administrative implementability of the response action. Decisions regarding future use of the area around the facility are not yet definite enough to determine whether this alternative would be consistent with the likely final remedy for the surrounding operable unit. The current conditions in the facility require expedited action. Therefore, because the exigencies of the situation do not allow resolution of the uncertainties involved in the containment alternative, it will not be evaluated in detail.

The following four alternatives have been considered and will be discussed in detail to assist the selection of a response action.

- No action

- Continued S\&M

- Decontamination and/or stabilization of facility with reduced S\&M

- Decontamination and/or stabilization of facility, followed by demolition of its structures.

\subsection{COMMON ELEMENT}

With the exception of the no-action alternative, each of the alternatives will result in generation of waste. Therefore, waste management is a common element to each of these alternatives.

Contaminated waste for which no reuse, recycle, or decontamination option is identified would be assigned an appropriate waste designation (e.g., TRU, radioactive, dangerous, or mixed). 
DOE/RL-96-93

Rev. 0

Most of the waste generated during implementation of these alternatives will be disposed to the Environmental Restoration Disposal Facility (ERDF) in the 200 West Area of the Hanford Site. The ERDF has been evaluated as the waste disposal option because it is an engineered facility that generally provides greater duration of protection to human health and the environment and is more cost effective than other disposal options.

The ERDF is designed to be an isolation structure for long-term disposal of wastes generated from Hanford Site remediation activities. Construction and operation of the ERDF were authorized via a separate Record of Decision and are not within the scope of this EE/CA (EPA 1995). Disposal of waste generated during decommissioning activities is authorized by the DOE's ERDF explanation of significant differences (EPA et al. 1996). The ERDF is designed to meet Resource Conservation and Recovery Act of 1976 (RCRA) minimum technological requirements for landfills, including standards for a double liner, a leachate collection system, leak detection, and final cover. Waste may be treated as necessary to meet the ERDF waste acceptance criteria (e.g., stabilization of lead, mercury, and friable asbestos) or to minimize volumes (e.g., by crushing, sizing, sorting, etc.). There are no foreseeable impacts to current ERDF disposal capacities as a result of the activities identified in this EE/CA.

TRU waste is defined by DOE Order 5820.2A (DOE 1988) as any waste, regardless of source or form, that is contaminated with alpha-emitting TRU radionuclides with half-lives greater than 20 years and in concentrations greater than 100 nanocuries per gram of the waste matrix. This waste would be stored at the Transuranic Waste Storage and Assay Facility in the 200 Area of the Hanford Site until a final disposal site is identified. If the Transuranic Waste Storage and Assay Facility becomes unavailable because of deactivation activities, the Central Waste Complex will be used to store the TRU generated by the 233-S Facility. Uncontaminated rubble that cannot be recycled would be disposed in one of the Hanford Site's inert waste landfills or other designated rubble pits approved for disposal of this material.

Both radioactive and nonradioactive liquid wastes might be encountered or generated during decommissioning. Radioactive solutions that could not be treated to meet the ERDF waste acceptance criteria would be packaged and transported to either the Hanford Site double-shell tank farms to be dispositioned with other radioactive liquids, or the Effluent Treatment Facility in the 200 East Area of the Hanford Site. Liquids may also be solidified at the Plutonium Finishing Plant in the 200 West Area of the Hanford Site and packaged for disposal. Nonradioactive liquids contaminated with hazardous constituents that could not be treated to meet ERDF waste acceptance criteria would be packaged and shipped to a permitted facility for storage, treatment, and/or disposal in compliance with applicable regulations.

\subsection{NO ACTION}

Under the no-action alternative, access to the facility would be restricted, but no action would occur to address the hazards posed by the facility; the 233-S Facility would be left to continue to deteriorate. Although Hanford Site institutional controls would continue to help prevent 
personnel or worker entry to the facility, releases of contaminants from the facility would ultimately occur.

Initial risks of the no-action alternative would be minimal, as contaminants would be expected to be confined within the facility and, barring an unusual event, the surrounding environment would be unaffected. The risks of both industrial hazard and radiological exposure will be nonexistent, as personnel entry into the facility will be prohibited.

Risks over time can be expected to increase as the 233-S Facility's deterioration progresses and the structural integrity of the facility and its systems is compromised. Eventually, the facility's decay can be expected to result in radiological releases to the environment with potential for exposure to workers in the 233-S Facility area and potentially the public, which will be accompanied by partial structural collapse.

\subsection{CONTINUED SURVEILLANCE AND MAINTENANCE}

The continued S\&M alternative will ensure that the 233-S Facility will be sustained in a safe condition until the year 2017 when final disposition of the REDOX Plant occurs. The facility will be maintained in a quiescent state for a considerable duration while ongoing preventive measures are implemented. These measures will include weekly radiological and industrial hazard monitoring (both inside and outside of the facility), accompanied by monthly filter changes on inter-space penetrations. The 233-SA Facility exhaust system filters will be tested on a bi-annual basis, and yearly safety inspections will provide comparative information for the tracking of facility deterioration. Major maintenance operations, such as the needed roof repair, will be performed to ensure the maintenance of safe conditions and the control of the ongoing deterioration process. Additionally, limited decontamination and fixative application will occur to control the spread of radiological contamination.

Surveillance also includes groundwater monitoring and data evaluation. An existing upgradient and downgradient groundwater monitoring network is in place in the vicinity of 233-S Facility. The existing network is monitored as part of the Hanford Site Operational Groundwater Monitoring Program; no direct cost results to the 233-S project for implementing this program.

The prime goal of this alternative is to prevent radiological environmental releases and to avoid industrial accidents. Adoption of the S\&M alternative extends the life of the facility for approximately the next 20 years, during which time deterioration will progress and unusual events may occur. Severe weather conditions can create facility conditions amenable to radiological releases, and long-term aging of engineered controls can lead to eventual failure. These conditions, accompanied by minimum surveillance efforts, could result in an unplanned radiological release.

Because minimal surveillance will not readily detect facility decay (e.g., system corrosion or structural breakdown), preventive maintenance may not occur in time and response actions may 
be required. This approach could result in contamination spread and possibly a major fissile material inventory release. An ongoing S\&M program would have to become increasingly more labor-intensive and incorporate periodic characterization efforts to counter these conditions. Such conditions will ultimately lead to increased worker exposure to radioactive material and contamination.

While the magnitude of a continued S\&M program should be controlled to conserve funding and be responsive only to safety issues, the growth of the program should be planned to account for progressive 233-S Facility deterioration. Data evaluation. inspection/observations, and future facility plans should be factored into the continued S\&M planning and implementation.

A variety of waste streams may be generated in the performance of S\&M and shall be appropriately characterized, packaged, and disposed. Contaminated wastes that meet the ERDF waste acceptance criteria will be disposed at the ERDF. and other wastes will be managed as appropriate to comply with identified ARARs. The yearly estimated cost associated with a continuous S\&M program (as described in Section 4.3.1) is presented in Table 4-1, along with a projection of these costs over the 20-year span anticipated for initiation of REDOX Plant D\&D efforts. The upgrade value (i.e., $\$ 2$ million over 20 years) is the cost required to initially repair the roof.

Table 4-1. Cost Estimates: Continued Surveillance and Maintenance.

\begin{tabular}{|l|r|}
\hline \multicolumn{1}{|c|}{ Item } & Estimated Cost \\
\hline S\&M & $325,000.00$ \\
\hline Upgrades $^{\mathfrak{c}}$ & $100,000.00$ \\
\hline & Total \\
\hline Total for 20 Years & $425,000.00$ \\
\hline
\end{tabular}

${ }^{a}$ Costs are on an annual basis.

b Total costs for this alternative would depend on the number of years of S\&M prior to initial decommissioning.

c The S\&M upgrades assume cost for a new roof that will last for at least 20 years. Cost of roof includes decontamination and disposal of contaminated roof material as well as construction of a new roof. The S\&M upgrades do not include costs associated with potential structural modifications, ventilation upgrades, or installation of remote monitoring systems

The identified costs do not account for increased efforts that would be anticipated if facility deterioration is accelerated or if an unusual deleterious event occurred that necessitated emergency response and 200 Area cleanup. These costs also do not include facility disposition. 
Rev. 0

\subsection{DECONTAMINATION WITH REDUCED SURVEILLANCE AND MAINTENANCE}

The primary goals of this alternative are to remove the bulk inventory of fissile material from the facility and to decontaminate building surfaces to radiation levels that can be readily managed by a minimum S\&M program. The S\&M would be continued until final disposition of the REDOX complex occurs in approximately the year 2017 (20 years).

Initial decontamination efforts in the 233-S Facility will be directed toward cleaning of the process hood so that in-hood operation can be performed by workers. Cleaning will involve collecting and removing debris on the process hood floor followed by thorough vacuuming and wiping to remove contaminant particles. This latter effort may be accompanied by misting operations to remove particulates from the air. These cleaning efforts will most likely be followed by an additional misting of a fixative solution that will serve to cleanse the air of particulates and fix them to in-hood surfaces. Operations to remove the process system, and hence the bulk of the fissile material inventory, will then proceed. With the completion of these operations, the fissile material inventory in the 233-S and 233-SA buildings will be reduced to a level where nuclear concerns are eliminated and only radiological concerns remain.

Following removal of the process system, decontamination efforts in the facility will involve the removal of other equipment and systems and the use of various decontamination technologies to remove contamination from facility surfaces. Contaminants that cannot be readily removed will be fixed by the application of an adhesive protective coating. After this scope of work has been completed, a minimal-effort S\&M program will be implemented until final disposition of the REDOX complex occurs.

The various waste forms (e.g., TRU, LLW, mixed, and hazardous) will be packaged and appropriately disposed of during the decontamination efforts. Waste generated during S\&M will be expected to be minimal and will be disposed of as it is generated.

The major risk associated with this alternative is the safety of workers during the process system removal operations. Because appreciable quantities of fissile material are contained in the various components of the process system, the sectioning, packaging, and handling operations will create a potential for radiological releases with the resultant contamination of workers and the facility. While the quantity of fissile material in the process system is sufficient to raise criticality concerns, the disassembly methods, handling, packaging, and assay operations to be employed will ensure preventive control.

Until the major inventory of fissile material is removed from the facility, the risks associated with uncontrolled credible natural phenomenon events (e.g., seismic actions or high-velocity winds) will exist. After removal of the fissile material inventory and decontamination, only extremely low concentration environmental releases could be expected from these events. 
Risks associated with the S\&M duration may include the potential migration of contaminants from the underlying systems of the facility into the vadose zone and possible minor releases of contaminants from the exhaust system into the atmosphere. Industrial accidents that could occur during the process system removal operations and $S \& M$ are the only additional risks that may be considered credible.

The only issue associated with this alternative is determining whether fixed contamination can be readily maintained over a short duration while implementing a minimal S\&M program. An extension of this period could result in facility conditions that may require a substantial increase in S\&M operations. Monitoring for subsurface contaminant migration is one S\&M activity that would need to be performed at specific time intervals to evaluate facility deterioration and contaminant release characteristics. Although a groundwater monitoring program is currently in place for Hanford Site operations, the adequacy of the existing program would require further evaluation in the removal action design report if this alternative is implemented. Table 4-2 presents estimated costs and durations associated with removal of the major fissile material inventory, partial facility decontamination and waste disposal, and implementation of a minimal S\&M program.

\subsection{DECONTAMINATION AND DEMOLITION}

The primary goals of this alternative are to remove the bulk inventory of fissile material from the facility, modify the facility to an acceptable state for demolition through decontamination, remove the facility and its associated systems by demolition/dismantlement operations, and dispose of the various waste forms generated in these operations. The fissile material inventory removal and facility decontamination will be achieved as previously discussed in Section 4.4.

If decontamination of facility surfaces can successfully reduce contamination levels to releasable standards, conventional demolition can be employed with all waste products being disposed at onsite land fills. More realistically, decontamination of facility surfaces will probably only be partially achieved and fixatives will be used to immobilize permeated surface contaminants. This facility condition will necessitate the use of controlled dismantlement for at least some portions of the facility, with most waste materials being disposed of as LLW. Controlled dismantlement will involve the use of specialized facility sectioning techniques, atmospheric control enclosures, massive structure handling, and waste disposal.

Facility removal will include both the 233-S and 233-SA buildings and subsurface systems and structures to a depth of $0.91 \mathrm{~m}(3 \mathrm{ft})$. Piping and trenches extending away from the buildings may be removed as necessary to accommodate the removal action for the structures. In general, the subsurface structures are only included to a depth of $1 \mathrm{~m}(3 \mathrm{ft})$. Underground piping and trenches extending away from the facility are only included in the scope to a distance of $1 \mathrm{~m}$ ( $3 \mathrm{ft}$ ) from the walls of the structure, although additional piping or trenches might be removed as necessary to accommodate the removal action for the structure. Grossly contaminated substructures will be removed, isolated, fixed, or stabilized as appropriate. Uncontaminated structures or portions of structures associated with this facility within this scope might be 
Table 4-2. Cost and Schedule Estimates: Decontamination with Reduced Surveillance and Maintenance.

\begin{tabular}{|c|c|c|}
\hline Facility/Room & $\begin{array}{c}\text { Estimated Time Required } \\
\text { for Decontamination } \\
\text { (months) }\end{array}$ & $\begin{array}{c}\text { Estimated Cost for } \\
\text { Decontamination and } \\
\text { Disposal }^{2}\end{array}$ \\
\hline Mobilize & 2 & $\$ 86,000.00$ \\
\hline Nonprocess Pipe Gallery & 3 & $267,000.00$ \\
\hline Isolate process hood & 9 & $308,000.00$ \\
\hline $\begin{array}{l}\text { Remove vessels and decontamination } \\
\text { hood }\end{array}$ & 12 & $744,000.00$ \\
\hline Remove ductwork & 9 & $451,000.00$ \\
\hline Decontamination structure & 5 & $211,000.00$ \\
\hline Closeout/demobilize & 0.5 & $102,000.00$ \\
\hline Project management & & $2,996,500.00$ \\
\hline Equipment & & $240,000.00$ \\
\hline Consumables & & $495,000.00$ \\
\hline 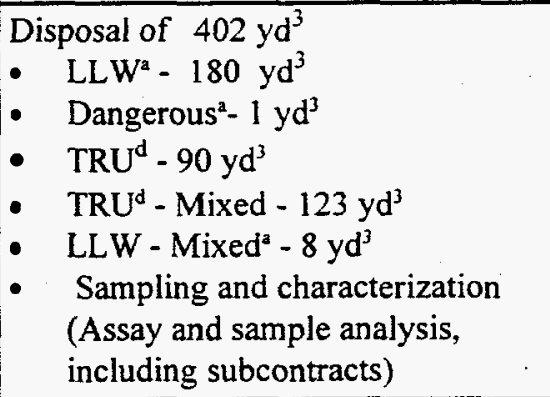 & & $\begin{array}{r}9,900.00^{\circ} \\
55.00^{\circ} \\
\\
337,284.00 \\
477,794.00 \\
440.00^{\circ} \\
1,308,000.00\end{array}$ \\
\hline \multicolumn{3}{|c|}{ Annual Activities (\$/yr) } \\
\hline \multicolumn{2}{|l|}{ S\&M } & $100,000.00$ \\
\hline \multicolumn{2}{|c|}{ S\&M Upgrades (roof foaming every 5 years) } & $50,000.00$ \\
\hline \multicolumn{2}{|l|}{ Total of Annual Activities for 20 years } & $3,000,000.00$ \\
\hline & Grand Total ${ }^{c}$ & $11,183,973.00$ \\
\hline
\end{tabular}

${ }^{a}$ Key cost assumptions include disposal of low-level radioactive waste at the ERDF at $\$ 55 / \mathrm{yd}^{3}$.

b Includes the costs of waste disposal, container procurement, waste transportation, and waste characterization. No cost is associated with disposal of inert (nonhazardous waste) demolition waste.

c Based upon the anticipated decommissioning of REDOX in the year 2016 (20 years) with no escalation cost.

d Central Waste Complex $-\$ 3,884.50 / \mathrm{yd}^{3}$ mixed waste and $\$ 3747.60 / \mathrm{yd}^{3}$ TRU waste.

removed or otherwise addressed as necessary to facilitate implementation of a removal action. Contaminated and uncontaminated soil for a distance of $1 \mathrm{~m}(3 \mathrm{ft})$ from the walls and floors of the structure might be moved or removed as necessary to implement the removal action for the structures; however, the scope of this removal action does not include soil, groundwater, or waste site remediation. Further soil remediation and/or capping will be conducted in coordination with 


\section{DOE/RL-96-93}

Rev. 0

the applicable operable unit. The various waste forms (e.g., TRU, LLW, mixed, and hazardous) will be packaged and appropriately disposed of during the various operations.

The major risk associated with this alternative is the safety of workers involved in both the radiological aspects of the process system removal and decontamination, and the industrial aspects of facility demolition/dismantlement. These risks are related to the potential release of contamination during operations and the hazards associated with construction activities. Risks associated with credible natural phenomenon events (e.g., seismic actions and high-velocity wind) will continue to exist until the fissile material inventory is removed from the facility. These risks will diminish as the facility removal efforts progress.

The disposal of the fissile material inventory in the 233-S Facility and the immediate removal of the facility and its systems and auxiliary structures are the most direct resolution of its impending hazards. While concerns for operational methods and technology utilization will be encountered and resolved during removal actions, no major issues exist that may compromise this alternative. Estimated costs and durations associated with removal of the fissile material inventory, facility decontamination, facility demolition/dismantlement, and waste disposal are presented in Table 4-3.

\section{Table 4-3. Cost and Schedule Estimates: Decontamination, Demolition, and Disposal.}

\section{(Page 1 of 2)}

\begin{tabular}{|c|c|c|}
\hline Facility/Room & $\begin{array}{c}\text { Estimated Time } \\
\text { Required for } \\
\text { Decontamination and } \\
\text { Demolition } \\
\text { (months) }\end{array}$ & $\begin{array}{l}\text { Estimated Cost for } \\
\text { Decontamination, } \\
\text { Demolition, and } \\
\text { Disposal }\end{array}$ \\
\hline Mobilize & 2 & $\$ 86,000$ \\
\hline Nonprocess Pipe Gallery & 3 & $\$ 267,000$ \\
\hline Isolate process hood & 9 & $\$ 308,000$ \\
\hline $\begin{array}{l}\text { Remove vessels and decontamination } \\
\text { hood }\end{array}$ & 12 & $\$ 744,000$ \\
\hline Remove ductwork & 9 & $\$ 451,000$ \\
\hline Decontamination structure & 5 & $\$ 211,000$ \\
\hline Dismantle facilities & 10 & $\$ 1,038,000$ \\
\hline Remove subgrade structure & 5 & $\$ 92,000$ \\
\hline Backfill/cap & 0.5 & $\$ 566,000$ \\
\hline Closeout/demobilize & 0.5 & $\$ 102,000$ \\
\hline Project management & -- & $\$ 5,993,000$ \\
\hline Equipment & & $\$ 480,000$ \\
\hline Consumables & & $\$ 990,000$ \\
\hline
\end{tabular}


DOE/RL-96-93

Rev. 0

Table 4-3. Cost and Schedule Estimates: Decontamination, Demolition, and Disposal.

(Page 2 of 2)

Disposal of $871 \mathrm{yd}^{3}$

- $L L W^{2}-461 y^{3}$

- LLW - Mixed $-9 y d^{3}$

- Dangerous $\mathrm{s}^{\mathrm{a}}-1 \mathrm{yd}^{\mathrm{3}}$

- Clean Rubble $-187 \mathrm{yd}^{3}$

- TRU - Mixed $-123 \mathrm{yd}^{3}$

- $T R U^{c}-90 \mathrm{yd}^{3}$

- Sampling and characterization (Assay and sample analysis, includes subcontracts)

\begin{tabular}{|l|c|c|} 
& & \\
\hline Total & - & \\
\hline
\end{tabular}

Key cost assumptions include disposal of low-level radioactive waste at the ERDF at $\$ 55 / \mathrm{yd}^{3}$.

${ }^{b}$ Includes the costs of waste disposal, container procurement, waste transportation, and waste characterization. No cost is associated with disposal of inert (nonhazardous) demolition waste.

c Central Waste Complex- $\$ 3,884.50 / \mathrm{yd}^{3}$ mixed waste and $\$ 3,747.60 / \mathrm{yd}^{3}$ TRU waste. 
DOE/RL-96-93

Rev. 0 
DOE/RL-96-93

Rev. 0

\subsection{COMPARATIVE ANALYSIS OF ALTERNATIVES}

The CERCLA requires that the removal action alternatives be evaluated against the following nine criteria:

- Overall protection of human health and the environment

- Compliance with Federal and state laws and regulations

- Long-term effectiveness and permanence

- $\quad$ Reduction of toxicity, mobility, or volume through treatment

- $\quad$ Short-term effectiveness

- Implementability

- Cost

- State acceptance

- Community acceptance.

\subsection{OVERALL PROTECTION}

This criterion evaluates whether the alternative achieves adequate overall elimination, reduction, or control of risks to human health and the environment posed by the likely exposure pathways and draws on the assessment of the other evaluation criteria identified above. Reducing the potential threat to acceptable levels is a threshold requirement and is the primary objective of the remedial program. The evaluation of this criteria was based on qualitative analysis and assumptions regarding the inventory of radionuclides.

The no-action alternative does not provide overall protection to human health and the environment. As the facility deteriorates, over time the contamination in the facility will be released to the environment. Loose alpha contamination would expose Hanford Site workers, and potentially the public, to an unacceptable dose of radiation.

Continued S\&M provides adequate overall protection of human health and the environment, although the level of effort required to maintain protection would increase over time. The ventilation system, structure, and roof of the facility would require extreme modification, repair, and replacement in order to maintain confinement of loose alpha contamination. There is no time frame in which the S\&M alternative would achieve all the removal action objectives since S\&M costs are not reduced or eliminated over the life cycle of the 233-S Facility. Furthermore, the principal threat of release to the environment (airborne alpha) is not reduced or eliminated because inventory removal or structural modifications are not proposed.

The third and fourth alternatives would remove or stabilize existing loose alpha contamination, thereby eliminating pathways for release to the environment. Process piping containing asbestos and potentially toxic and corrosive liquids would be removed, providing overall protection of human health and the environment. The friable asbestos would be made nonfriable and 
Rev. 0

contaminated liquids would be treated to ensure safe disposal. Alternatives three and four clearly meet the removal action objectives through removal of radiological and hazardous inventories; mitigation of radiological, hazardous, and industrial hazards to workers; disposal of waste to ERDF; and compliance with ARARs. However, alternative four provides a more efficient project life cycle cost by initiating dismantlement of the 233-S Facility immediately after decontamination activities and inventory removal occurs.

\subsection{COMPLIANCE WITH APPLICABLE OR RELEVANT AND APPROPRIATE REQUIREMENTS AND OTHER STANDARDS}

The ARARs are standards, requirements, criteria, or limitations promulgated under Federal or state environmental laws that must be met or waived to the fullest extent practicable for actions conducted under CERCLA. Only the substantive provisions of requirements that are ARARs must be met (or waived) for actions conducted entirely onsite (CERCLA Section 121 [d][2]). Such onsite actions are exempted from obtaining Federal, state, and local permits (CERCLA Section $121[\mathrm{e}][1])$. To-be-considered materials are nonpromulgated standards that may be referenced to the extent necessary for the response action to be adequately protective; they include DOE orders, proposed regulations, and nonpromulgated regulatory guidance.

The no-action alternative would not attain compliance with ARARs requiring that facilities be maintained in a manner protective of human health and the environment. Key ARARs for alternatives two, three, and four include waste management standards, air emission control standards, radiation control standards, and standards for protection of cultural and ecological resources. The scope of the expedited response action does not include remediation of subsurface structures or soil or groundwater contamination; therefore, environmental cleanup standards have not been identified as ARARs. Remediation of soil and groundwater are addressed in the remedial action project; however, all removal action activities will be coordinated with the remedial action project. Other standards to be met by the response action include various DOE, Federal, and state worker safety standards.

\subsubsection{Waste Management Standards}

RCRA regulates management and disposal of hazardous (dangerous) waste. Implementing regulations in the Washington Administrative Code (WAC) 173-303 require identification and appropriate management of dangerous wastes, the dangerous component of mixed wastes, and identifies standards for treatment and disposal of these wastes. These requirements are applicable to any wastes existing or generated in the 233-S Facility that are designated, in accordance with WAC 173-303, as a dangerous or mixed waste. WAC 173-304 requires identification and appropriate management of solid wastes. It is applicable to any solid waste generated at the 233-S Facility. 
Performance objectives for land disposal of low-level radioactive waste are provided in 10 CFR 61, Subpart C. Although not applicable to DOE facilities, these standards are relevant and appropriate to any disposal facility for low-level and mixed waste generated at the 233-S Facility.

The S\&M alternative and the decommissioning alternatives will generate solid, dangerous, low-level, and/or mixed waste. Under all of these alternatives, actions proposed to manage such waste would satisfy the waste management ARARs. All wastes would be evaluated and managed in compliance with the appropriate requirements. Prior to disposal, dangerous, low-level, or mixed wastes would be managed in a protective manner to prevent releases to the environment or inadvertent exposure to workers. The ERDF is engineered to meet RCRA minimum technological requirements for landfills, including standards for a double liner, a leachate collection system, leak detection, and final cover. The ERDF also meets the appropriate performance standards under 10 CFR 61 for disposal of LLW and mixed waste. Treatment requirements, if any, necessary to dispose of wastes in the ERDF would be identified in order to meet the ERDF waste acceptance criteria. Treatment may include stabilization, dewatering, encapsulation, or other readily available treatment methods. Packaging and transportation requirements for waste generated at the 233-S Facility will be identified and implemented prior to movement of any wastes. Any offsite facility to which dangerous wastes would be sent will first meet all RCRA administrative and substantive requirements. Any offsite shipment of waste will comply with appropriate U.S. Department of Transportation requirements.

\subsubsection{Air Emission Control Standards}

The Clean Air Act regulates both toxic and radioactive airborne emissions. Under implementing regulations found in 40 CFR 61 , Subpart $H$, and WAC 246-247, radionuclide airborne emissions from all combined operations at the Hanford Site may not exceed $10 \mathrm{mrem} /$ year effective dose equivalent to the hypothetical offsite maximally exposed individual. WAC 246-247 requires verification of compliance, typically through periodic confirmatory air sampling. WAC 173-400 establishes requirements for the control and/or prevention of the emission of air contaminants, including dust.

Health impacts to the public were estimated by considering the effects on the maximally exposed individual (MEI) and the collective effects on the population at large. The MEI is a hypothetical member of the public living near the Hanford Site, who, by virtue of location and living habits, could receive the highest possible radiation dose from radioactive effluents released from the Hanford Site. Expected average impacts to the general public are represented by the collective dose to the population within a radius of $80 \mathrm{~km}$. To estimate the dose to the MEI, a Clean Air Assessment Package 1988 (CAP-88) evaluation was run for the projected releases from the 233-S Complex (DOE-RL 1994; Parks 1992). Estimations were performed using the assumption that an emission control system is in place (e.g., one HEPA filter). However, it should be noted that all of the air emissions from the facility and the portable exhauster would pass though at least two banks of HEPA filters. The projected dose to the MEI is $5.94 \times 10^{-6} \mathrm{mrem} /$ year. This dose would not be expected to add significantly to the current offsite dose from Hanford Site 
DOE/RL-96-93

Rev. 0

operations. As reported in the Hanford Site Environmental Report for 1993 (Dirkes 1994), the potential dose from Hanford Site operations to the hypothetical offsite MEI during calendar year 1993 was $0.03 \mathrm{mrem}$. The potential dose to the local population from 1993 operations was 0.4 person-rem. The national average dose from natural sources is $300 \mathrm{mrem} / \mathrm{year}$, and the current DOE radiation limit for an individual member of the public is $100 \mathrm{mrem} / \mathrm{year}$. The potential dose from routine decommissioning operations is minuscule compared to both the national average dose from natural sources and the DOE limit, and no adverse public health effects would be expected as a result of this decommissioning activity.

The radionuclide emission standards apply to any fugitive, diffuse. and point-source air emissions of radionuclides generated at the 233-S Facility. If there is the potential for any non-zero radioactive emissions, best available radionuclide control technology would be required. If the action would generate an increase of toxic air pollutants to the atmosphere above the small quantity emission rates, implementation of best available control technology for toxics would be required. Alternatives three and four propose to use fixation of surface contaminants. misting, and HEPA filtration to provide emission control during decommissioning. Operations at the ERDF use standard construction techniques to control fugitive emissions during placement of wastes. These methods should adequately control fugitive emissions of radionuclides and toxic air pollutants and would therefore be considered best available radionuclide control technology and best available control technology for toxics for the proposed activities.

\subsubsection{Cultural and Ecological Resource Protection Standards}

The National Historic Preservation Act of 1966 (implemented via 36 CFR 800) requires Federal agencies to evaluate and mitigate adverse effects of Federal activities on any site eligible for inclusion on the National Register of Historic Places; additionally, the Archeological and Historical Preservation Act of 1974 requires action to recover and preserve artifacts in areas where activity may cause irreparable harm, loss, or destruction of significant artifacts. The Endangered Species Act of 1973 (implemented via 50 CFR 402) and WAC 232-12-297 prohibit activities that threaten the continued existence of listed species or destrcy critical habitat. The Migratory Bird Treaty Act makes it illegal to take, capture, or kill any migratory bird, or any part of nests or eggs of any such birds.

The 233-S Facility has been identified as part of an overall operation (REDOX Plant) that is eligible for inclusion on the National Register of Historic Places. Appropriate mitigation measures have been taken for the facility to comply with the National Historic Preservation Act of 1966 (see Section 2.1). No other potential cultural resource issues have been identified.

Threatened and endangered species are known to occur on the Hanford Site but are not likely to be present in the 200 Area. A facility-specific ecological review would be conducted prior to the decommissioning of the facility to verify that no potential adverse impacts exist regarding any threatened and endangered species or migratory birds. 
DOE/RL-96-93

Rev. 0

\subsubsection{Radiation Protection Standards}

The 10 CFR 835, "Occupational Radiation Protection." establishes radiation protection standards, limits, and program requirements for protecting workers and visitors from ionizing radiation resulting from the conduct of $D O E$ activities. It also requires that measures be taken to maintain radiation exposure as low as reasonably achievable. This regulation is applicable to all activities at the 233-S Facility.

A combination of personal protective equipment, personnel training, physical design features (e.g., confinement, remote handling, and shielded containers), and administrative controls (e.g., limiting time in radiation zones) would be used to ensure that the requirements for worker and visitor protection are met by alternatives two, three, and four. The decommissioning alternatives would also meet the requirements for maintaining exposure as low as reasonably achievable by decontaminating surfaces and fixing loose contamination prior to decommissioning. Individual monitoring would be performed as necessary to verify compliance with these requirements.

\subsubsection{Polychlorinated Biphenyls}

The Toxic Substances Control Act of 1976 (TSCA) and WAC 173-303 regulates the management and disposal of PCBs and PCB waste. Implementing regulations in 40 CFR 761 contain requirements for the management of spills and cleanup of materials suspected to contain $\mathrm{PCB}$ waste. The ERDF is authorized to accept certain PCB waste for disposal. All waste at the 233-S Facility suspected to contain PCBs will be evaluated to determine whether it meets the ERDF waste acceptance criteria. Any PCB waste that does not meet the ERDF waste acceptance criteria will be sent to an onsite PCB storage area that meets the substantive requirements of TSCA, and will be transported for disposal at a TSCA-approved disposal facility.

\subsubsection{Asbestos}

Removal and disposal of asbestos and asbestos-containing materials are regulated under the Clean Air Act (40 CFR 61, Subpart M) and Occupational Safety and Health Administration (OSHA) (29 CFR 1910.1101 and WAC 296-62). These regulations provide for special precautions to prevent exposure of workers or airborne emissions of asbestos fibers during removal actions and 40 CFR 61.52 identifies packaging requirements. All of the alternatives shall comply with these requirements for any actions that will disturb or otherwise manage or dispose of asbestos materials.

\subsubsection{Environment, Safety, Quality, and Health Requirements}

Worker protection standards are described in OSHA regulations, national consensus standards, and DOE orders (e.g., 29 CFR 1910; 29 CFR 1926; NFPA 1990; and WAC 296). Exposure limits, personnel protection requirements, and decontamination methods for hazardous chemicals are established by 29 CFR 1910. Additionally, 29 CFR 1910 requires identification and mitigation of physical hazards posed by a facility to workers, including but not limited to, 
confined spaces, falling hazards, fire, and electrical shock. The 29 CFR reference provides requirements for worker safety during construction activities.

The DOE orders establish requirements relating to safety, health, and environmental protection. The substantive requirements of these standards will be met for any S\&M decommissioning, or demolition activities. Site- and activity-specific requirements and controls will be identified in final design and work plan documents, including contingency plans and emergency response plans. The following DOE order requirements have been determined to contain requirements that are to be considered for one or more of the alternatives:

- $\quad$ Certain requirements in DOE Order 4330.4B. Maintenance Management Program (DOE 1994b), regarding facility maintenance are relevant and appropriate to all the alternatives except the no-action alternative.

- The requirements in DOE Order 5400.5. Radiation Protection of the Public and the Environment (DOE 1993b), for limiting exposure of the public to radioactive releases would be relevant and appropriate to all alternatives.

- The requirement in DOE Order 5440.1E, National Environmental Policy Act Compliance Program (DOE 1992a), to address National Environmental Policy Act of 1969 (NEPA) values would be relevant and appropriate to all alternatives.

- $\quad$ The requirement in DOE Order 5480.3, Safety Requirements for the Packaging and Transportation of Hazardous Materials, Hazardous Substances and Hazardous Waste (DOE 1985), to comply with U.S. Department of Transportation or equivalent packaging standards are relevant and appropriate to all of the alternatives that generate waste for disposal, and the requirements of the order for special handling of plutonium-bearing wastes are relevant and appropriate for the decommissioning alternatives.

- $\quad$ The requirements in DOE Order 5480.7A, Fire Hazards Analysis (DOE 1993a), to analyze and provide controls for fire hazards are relevant and appropriate to all alternatives.

- The requirements in DOE Order 5480.20A, Personnel Selection, Qualification and Training (DOE 1994a), are relevant and appropriate for all alternatives except the noaction alternative.

- The requirements in DOE Order 5480.21, Unreviewed Safety Questions (DOE 1991), to evaluate changes for potential safety impacts are relevant and appropriate to all alternatives.

- The requirements in DOE Order 5480.22, Technical Safety Requirements (DOE 1992c), to establish bounding conditions for safety operations are relevant and appropriate to all alternatives. 
- The requirements in DOE Order 5480.23, Nuclear Safety Analysis Reports (DOE 1992b), to identify hazards, analyze hazards and accidents, and identify controls and mitigation measures to safely manage the hazards are relevant and appropriate to all alternatives.

- $\quad$ The requirements in DOE Order 5480.24, Nuclear Criticality Safety (DOE 1992d), to analyze potential criticality hazards and identify controls to manage such hazards are relevant and appropriate to all alternatives.

- The requirements in DOE Order 5480.28, Natural Phenomena Hazards Mitigation (DOE 1993b), to analyze potential hazards from natural phenomena and identify appropriate mitigation measures are relevant and appropriate for all alternatives.

- The requirement in DOE Order 5480.31, Start-up and Restart of Nuclear Facilities (DOE 1993c), to review the status of readiness is relevant and appropriate for all alternatives except the no-action alternative.

- The requirements in DOE Order 5820.2A, Radioactive Waste Management (DOE 1988), for management of LLW are relevant and appropriate for all alternatives except the noaction alternative. The requirements for the management of TRU waste would be relevant and appropriate to the decommissioning alterative if such an alternative generated one or more packages of waste that contain greater than $100 \mathrm{nCi} / \mathrm{g}$ of TRU constituents at the time of assay.

- $\quad$ The requirements in DOE Order 6430.1A, General Design Criteria (DOE 1989), for demolition of structures are relevant and appropriate to the demolition alternative.

\subsection{LONG-TERM EFFECTIVENESS}

The long-term effectiveness and permanence criterion assesses whether the alternative leaves an unacceptable risk after remedial activities have concluded. The no-action alternative greatly increases risk in the long term by allowing loose alpha contamination to be released from the 233-S Facility causing an unacceptable dose to Hanford Site workers and potentially the public.

Under the S\&M alternative, risk would increase rather than decrease in the long term due to the increasing difficulty of maintaining the integrity of the facility and confinement of loose alpha contamination. Ultimately, the facility would require major upgrades beyond the scope of routine maintenance, or a decommissioning option would have to be implemented. Major upgrades may include sealing structural cracks that develop with facility deterioration, maintaining/repairing the exhaust ducting and blower system, sealing subsurface drainage systems, and possible excavating/removing subsurface contaminated structures (i.e., the pipe trench system and abandoned subsurface filter house). 
Alternatives three and four provide a high degree of long-term effectiveness by removing and/or stabilizing alpha contamination and residual fissile isotopes from a condition where it is potentially subject to release, to a readily-contained condition. Process piping and tanks containing residual fissile isotopes and radiologically contaminated portions of the building structure will be treated and decontaminated as necessary for safe disposal. Alternative four, because it includes demolition of the buildings and subsurface structures extending away from the buildings, would preclude the need for any further S\&M at the facility and, therefore, would provide the greatest long-term effectiveness.

\subsection{REDUCTION OF TOXICITY, MOBILITY, OR VOLUME}

This criterion, which includes reducing toxicity, mobility, or volume through treatment, assesses whether the alternative permanently and significantly reduces the hazard posed. This could be accomplished by destroying the contaminants, reducing the quantity of contaminants, or irreversibly reducing the mobility of the contaminants.

The no-action alternative provides no reduction in toxicity, mobility or volume. The S\&M provides no near-term reduction in toxicity, mobility, or volume through treatment. Toxicity would be reduced for radioactive contaminants as the contaminants decay over time, but for long-lived radionuclides such as plutonium (alpha contamination) and nonradioactive contaminants, this would not be a practical means of reducing the risks.

Both alternatives three and four would reduce the mobility of alpha contamination by removing airborne alpha via HEPA filtration and through application of fixative sprays. Loose and smearable radioactive contaminants will be removed through decontamination. Nonradioactive contaminants such as lead, asbestos, nitric acid, and sodium nitrate will be treated if necessary to meet ERDF waste disposal criteria. Mobility of waste will be reduced through disposal in the ERDF facility or through stabilization of contaminants left in place (alternative three). Volume reduction will be achieved as necessary by using mechanical methods where possible to separate uncontaminated building components or to physically compact volumes of waste going to ERDF. Mobility of TRU waste will be reduced through removal and re-packaging for safe storage at a TRU waste storage facility on the Hanford Site.

\subsection{SHORT-TERM EFFECTIVENESS}

This criterion assesses whether the alternative provides adequate protection of human health (including workers) and the environment during the removal action and assesses how long it will take for the action to achieve the removal action objectives. The no-action alternative does not pose immediate risk to workers because entry will not be allowed to the 233-S Facility and, therefore, no immediate exposure will occur: However, it is unknown how long confinement will be maintained without active controls. Radiological contamination would be released over 
time, presenting a potentially unacceptable dose to Hanford Site workers and possibly to the public. The no-action alternative will never achieve the removal action objectives.

Because public access to the 200 Area is currently restricted and S\&M activities are generally sufficient to contain hazardous substances within the facility, the second alternative would be effective in the short term in providing protection of the public and environment. The requirement to continue entering the facility for $S \& M$ presents an increasing risk to workers because of the aging condition of the facility. Workers would be continually exposed to radiological contamination. Increasing maintenance requirements due to deterioration will likely increase the risk of radiological exposure and industrial accidents even in the short term.

Alternatives three and four, which both include decontamination, provide adequate protection of human health and the environment during implementation. The primary risk to the public and environment would be from the spread of airborne alpha contamination during decontamination activities in the process hood area. The risk would be mitigated by either removing contaminants from surfaces or fixing the contamination by application of a plasticized mist prior to removal of equipment and structures.

The vast majority of the radiological material is inside the pipes and vessels of the abandoned process equipment. The NDA and criticality evaluation of the process equipment have concluded that an accidental criticality ${ }^{1}$ is highly unlikely. However, due to uncertainty in the NDA and the moisture content of the residual plutonium, additional care will be taken to ensure that the assumptions of the criticality evaluation are valid. The exhaust ducting and other system components are suspected to contain small quantities of fissile material. Field evaluations will be required to verify fissile content and ensure the safe dismantlement and disposal of the exhaust system and components.

Although alternative three removes contaminants from surfaces or fixes contamination, the shortterm effectiveness is dependent on the level of contamination that was fixed and the rate in which recontamination could occur. For a short period of time, alternatives three and four would pose a somewhat increased risk to workers than the S\&M alternative, which is primarily associated with non-routine decontamination and standard industrial risks associated with demolition. Alternative three has somewhat less near-term risk to workers than alternative four, because alternative three does not include major demolition activities. However, the risk would be (at best) deferred or at worst, would be increased to future workers due to building deterioration.

Appropriate precautions would be taken to protect workers from industrial hazards during either alternatives three or four. The estimated $1.5 \mu \mathrm{Ci}$ of smearable alpha contamination throughout the facility is not likely to significantly impact workers, who would be dressed in protective clothing and equipped with respirators or other breathing apparatus. Further protection would be provided by using continuous air monitors that would detect any airborne activity. In addition to

1 "Criticality" is a self- activated, uncontrolled nuclear-chain reaction. 
exposure limitations provided by administrative control levels, emissions controls would likely limit releases to the building's atmosphere to below the detection levels of the 296-S-7W stack effluent sampling and monitoring systems.

Alternatives three and four would not be expected to significantly increase the annual radionuclide emissions to the atmosphere above the current levels. The majority of the contaminants are contained within the main process vessels, which, when removed, would reduce the potential for releases of air emissions. Activities under alternative three or four would be conducted within temporary confinements using continuous air monitors.

\subsection{IMPLEMENTABILITY}

The implementability criterion assesses whether the alternatives are technically and administratively feasible. The no-action alternative is implementable. The S\&M alternative would also be implementable, and consists of continuing current practices; however, S\&M would become increasingly difficult to implement over time as the 233-S Facility continues to deteriorate. The third and fourth alternatives could be implemented using standard decommissioning techniques and existing technologies, as described in Sections 4.4 and 4.5.

\section{$5.7 \quad \operatorname{COST}$}

The cost criterion evaluates whether the alternatives are cost effective. The costs for the no-action alternative are negligible in the long-term. The costs of the S\&M alternative are estimated based on the costs associated with current $S \& M$ but do not include estimates of the additional costs that would be incurred for surveillance as the condition of the building deteriorates. The annual cost is shown in Table 4-1. This cost, at a minimum, would be incurred annually as long as the 233-S Facility remains in its current condition. The facility would require a new roof or extensive repairs to the portions of the roof subject to cracking failure and repairs to the cracks in the concrete structure, which continue to increase in length from exposure to extreme weather conditions. These major maintenance activities would cost several million dollars.

The costs for the third alternative (i.e., decontamination and disposal without demolition), are shown in Table 4-2. The total cost for this alternative is approximately $\$ 12$ million. The cost for the fourth alternative (decontamination, disposal and demolition), which is presented in Table $4-3$, is approximately $\$ 14$ million. 
Rev. 0

\subsection{STATE ACCEPTANCE}

The state acceptance criterion evaluates whether the technical and administrative concerns of the state have been addressed. The criterion also evaluates the position of the state concerning the preferred alternative. [This section to be completed after the public comment period.]

\subsection{COMMUNITY ACCEPTANCE}

The community acceptance criterion is an assessment of the response from the general public to the proposed action following a review of comments received on the EE/CA.

\subsection{OTHER CONSIDERATIONS}

In accordance with DOE orders and NEPA policies. DOE CERCLA documents are required to incorporate NEPA values, such as analysis of cumulative, offsite, ecological. and socioeconomic impacts, to the extent practicable.

Cumulative impacts ${ }^{1}$ are expected to be negligible as a result of implementation of any of the alternatives for the 233-S Facility presented by this EE/CA. Hanford Site manpower will be obtained from existing resources at the REDOX Plant, and when activities at 233-S Facility are completed, resources will be utilized for S\&M of buildings currently undergoing transition (PUREX and B-Plant). No negative impacts to REDOX Plant maintenance activities will occur due to action at the 233-S Facility since the only major activity remaining for maintenance upgrade at the REDOX Plant (i.e., installation of remote monitoring systems) will be complete before the 233-S Facility activities are initiated.

Hanford Site utilities and other infrastructure will not be impacted by the 233-S Facility activities because the 233-S Facility relies on temporary construction power and is not connected (by utility) to any other Hanford Site facilities. Transport of waste from 233-S Facility to Hanford Site disposal facilities may increase traffic flow in the area, but transport is not expected to cause any congestion problems or additional deterioration of offsite roadways. Other activities in the 200 Area include S\&M of deactivated facilities, deactivation of the Plutonium Finishing Facility, and management of waste storage and disposal facilities. Activities across the Hanford Site include remediation of waste sites and groundwater, facility deactivation and decommissioning, storage and removal of spent fuel contained in basins at the 100-K Area, and tank waste management.

\footnotetext{
${ }^{1}$ Cumulative impacts are impacts resulting from the incremental impact of the action when added to other past, present, and reasonably foreseeable future actions.
} 
It is not anticipated that any of the alternatives would substantially change overall impacts from activities in the Hanford Site's 200 Area. The offsite impacts include impacts to the public or the environment due to releases of contaminants resulting from an activity. The no-action and S\&M alternatives would not be expected to result in offsite impacts in the near term. Continued confinement of hazardous substances in the facility would become more difficult with time, and the potential for offsite impacts would increase. The third alternative (i.e., decontamination and disposal) and fourth alternative (i.e., decontamination, disposal, and demolition) would potentially result in airborne emissions of hazardous substances, but significant or long-term impacts are not expected.

Local and regional air quality would not be significantly affected by the proposed action. The facility would be maintained under negative pressure and exhausted through HEPA filters. and/or temporary greenhouses would be erected to maintain control of emissions.

None of the alternatives would be expected to have any adverse effects on surface or groundwater resources in the 200 West Area. A relatively small amount of soil directly under the structures might require disposal if it is determined to be contaminated.

None of the alternatives would be expected to significantly affect existing natural or cultural resources. None of the alternatives would be expected to affect native vegetation and wildlife in the vicinity of the facility. Appropriate measures were taken with respect to the potential historical significance of the 233-S Facility (see Section 2.1). Socioeconomic impacts from any of the alternatives would be minimal. The work force required for current $S \& M$ activities is small. The staff required to accomplish any of the demolition alternatives would be drawn from the existing S\&M and remediation work force at the Hanford Site or available subcontractors. 
DOE/RL-96-93

Rev, 0

\subsection{RECOMMENDED REMOVAL ACTION ALTERNATIVE}

Based on overall effectiveness, long- and short-term effectiveness, implementability, and current estimates regarding life cycle project cost, the recommended removal alternative for the 233-S Facility is to decontaminate and demolish the structures and dispose of wastes at the ERDF. This alternative removes the potential for a release of hazardous substances that could adversely impact human health and the environment, is protective of workers, reduces $S \& M$ costs, and is consistent with other cleanup activities in the 200 Area as well as in other areas of the Hanford Site. 
DOE/RL-96-93

Rev. 0 
DOE/RL-96-93

Rev. 0

\subsection{REFERENCES}

10 CFR 61, 1996, "Licensing Requirements for Land Disposal of Radioactive Waste," Code of Federal Regulations, as amended.

10 CFR 835, 1996, "Occupational Radiation Protection," Code of Federal Regulations, as amended.

29 CFR 1910, 1996, "Occupational Safety and Health Standards," Code of Federal Regulations, as amended.

29 CFR 1926, 1996, "Safety and Health Regulations for Construction," Code of Federal Regulations, as amended.

36 CFR 800, 1996, "Protection of Historic and Cultural Properties," Code of Federal Regulations, as amended.

40 CFR 61.52, 1996, "Emission Standard," Code of Federal Regulations, as amended.

40 CFR 300.415, 1996, "National Oil and Hazardous Substances Pollution Contingency Plan, Section 415, "Removal Action," Code of Federal Regulations, as amended.

50 CFR 402, 1996, "Inter Agency Cooperation-Endangered Species Act of 1973," Code of Federal Regulations, as amended.

Archaeological and Historic Preservation Act of 1974, 16 U.S.C. 469, et. seq.

BHI, 1996a, Criticality Evaluation for the 233-S Decontamination and Decommissioning

Project, BHI-00891, Rev. 0, Bechtel Hanford, Inc., Richland, Washington.

BHI, 1996b, Safety Analysis for the 233-S Decontamination and Demolition Project, BHI-00892, Rev. 0, Bechtel Hanford, Inc., Richland, Washington.

Chatters, J. C. and N. A. Cadoret, 1990, Archaeological Survey of the 200 East and 200 West Areas of the Hanford Site, Richland, Washington, PNL-7264, Pacific Northwest Laboratory, Richland, Washington.

Clean Air Act, 42 U.S.C. 7401, et. seq.

Comprehensive Environmental Response, Compensation, and Liability Act of 1980, 42 U.S.C. 9601 , et. seq. 
DOE/RL-96-93

Rev. 0

Cushing, C. E., 1995, Hanford Site National Environmental Policy Act (NEPA)

Characterization, PNL-6415, Rev. 7, Pacific Northwest Laboratory, Richland, Washington.

Dirkes, R. L., 1994, Hanford Site Environmental Report for Calendar Year 1993, PNL-9823, Pacific Northwest Laboratory, Richland, Washington

DOE, 1985, Safety Requirements for the Packaging and Transportation of Hazardous Materials, Hazardous Substances and Hazardous Waste, DOE Order 5480.3, U.S. Department of Energy, Washington, D.C.

DOE, 1988, Radioactive Waste Management, DOE Order 5820.2A, U.S. Department of Energy, Washington, D.C.

DOE, 1989, General Design Criteria, DOE Order 6430.1A, U.S. Department of Energy, Washington, D.C.

DOE, 1991, Unreviewed Safety Questions, DOE Order 5480.21, U.S. Department of Energy, Washington, D.C.

DOE, 1992a, National Environmental Policy Act Compliance Program, DOE Order 5440.1E, U.S. Department of Energy, Washington, D.C.

DOE, 1992b, Nuclear Safety Analysis Report, DOE Order 5480.23, U.S. Department of Energy, Washington, D.C.

DOE, 1992c, Technical Safety Requirements, DOE Order 5480.22, U.S. Department of Energy, Washington, D.C.

DOE, 1992d, Nuclear Criticality Safety, DOE Order 5480.24, U.S. Department of Energy, Washington, D.C.

DOE, 1993a, Fire Hazards Analysis, DOE Order 5480.7A, U.S. Department of Energy, Washington, D.C.

DOE, 1993b, Radiation Protection of the Public and the Environment, DOE Order 5400.5, U.S. Department of Energy, Washington, D.C.

DOE, 1993c, Start-up and Restart of Nuclear Facilities, DOE Order 5480.31, U.S. Department of Energy, Washington, D.C.

DOE, 1993d, Natural Phenomena Hazards Mitigation, DOE Order 5480.28, U.S. Department of Energy, Washington, D.C. 
DOE, 1994, Personnel Selection, Qualification and Training, DOE Order 5480.20A, U.S. Department of Energy, Washington, D.C.

DOE-EPS, 1992, The Future for Hanford: Uses and Cleanup. U.S. Department of Energy, Environmental Protection Services, Richland. Washington.

DOE-RL, 1994a, Radioactive Air Emissions Program. Notice of Construction for the Decommissioning of the 233-S Plutonium Concentration Facility Complex, DOE/RL-94-107, U.S. Department of Energy, Richland Operations Office, Richland Washington.

DOE, 1994b, Maintenance Management Program. DOE Order 4330.4B, U.S. Department of Energy, Washington, D.C.

EPA, 1995, Record of Decision, U.S. DOE Hanford Environmental Restoration Disposal Facility, January 1995, U.S. Environmental Protection Agency, Richland, Washington.

EPA, Ecology, and DOE, 1996, U.S. Department of Energy Environmental Restoration Disposal Facility - Hanford Site Benton County, Washington - Explanation of Significant Difference, U.S. Environmental Protection Agency, Washington State Department of Ecology, and the U.S. Department of Energy, Richland Operations Office, Richland, Washington.

Griffith, G. A., 1994, 233-S Plutonium Concentration Building Demolition (Letter, Log 062794-10-DOE, to C. R. Pasternak, U. S. Department of Energy, Richland Operations Office, July 11), Department of Community Trade and Economic Development, Office of Archaeology and Historic Preservation, Olympia, Washington.

Migratory Bird Treat Act, 16 U.S. C. 703, et. seq.

National Environmental Policy Act of 1969, 42 U.S.C. 4321, et. seq.

National Historic Preservation Act of 1966, 16 U.S.C. 470 , et. seq.

NFPA, 1990, National Electrical Code, NFPA 70, National Fire Protection Association, Quincy, Massachusetts.

Parks, B. S., 1992, User's Guide for CAP 88-PC, Version 1.0, U.S. Environmental Protection Agency, Las Vegas, Nevada.

Resource Conservation and Recovery Act of 1976, 42 U.S.C. 6901, et. seq.

SEG, 1995, Passive Neutron Survey of the 233-S Plutonium Facility, Project No. 22192, DCC-95-2505, Scientific Environmental Group, Inc., Richland, Washington. 
DOE/RL-96-93

Rev. 0

Toxic Substance Control Act of 1976, 15 U.S.C. 2601, et. seq.

WAC 173-303, “Dangerous Waste Regulations," Washington Administrative Code, as amended.

WAC 173-304, "Minimum Functional Standards for Solid Waste Handling," Washington Administrative Code, as amended.

WAC 173-400, "General Regulations for Air Pollution Sources," Washington Administrative Code, as amended.

WAC 232-12, "Permanent Regulations," Washington Administrative Code, as amended.

WAC 246, "Department of Health," Washington Administrative Code, as amended.

WAC 247, "Health Care Facilities Authority," Washington Administrative Code, as amended.

WAC 296, 1996, "Department of Labor and Industries," Washington Administrative Code, as amended.

WHC, 1988, Physical Status and Post Stabilization Activities Report for the 233-S Building, WHC-SD-DD-TI-028, Rev. 0, Westinghouse Hanford Company, Richland, Washington.

WHC, 1990a, Radiological Characterization of the 233-S Facility, WHC-SD-CP-TI-163, Rev. 0, Westinghouse Hanford Company, Richland, Washington.

WHC, 1990b, 233-S Facility Potential Chemical Hazards, WHC-SD-DD-TI-056, Rev. 0, Westinghouse Hanford Company, Richland, Washington. 
DOE/RL-96-93

Rev. 0

APPENDIX

PRELIMINARY HAZARD ASSESSMENT

OF THE ACTION ALTERNATIVES

A-i 
DOE/RL-96-93

Rev. 0

A-ii 
DOE/RL-96-93

Rev. 0

\section{APPENDIX CONTENTS}

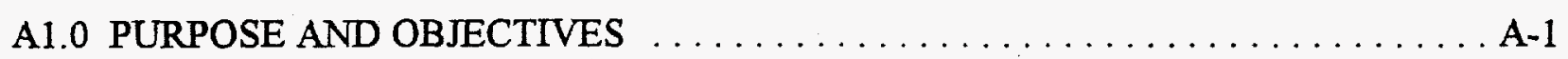

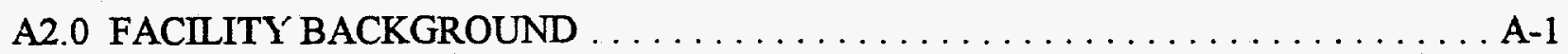

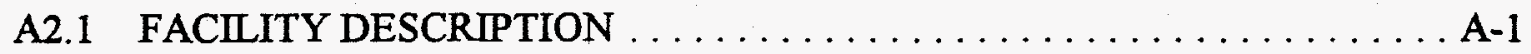

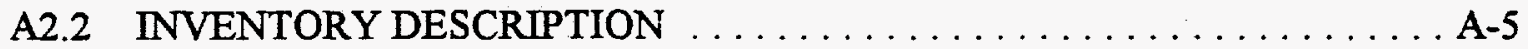

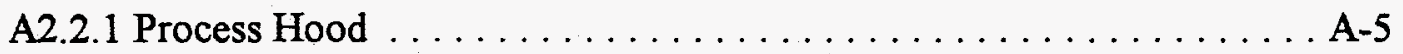

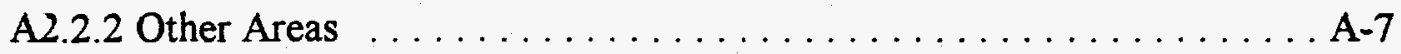

A3.0 SUMMARY HAZARDS EVALUATION $\ldots \ldots \ldots \ldots \ldots \ldots \ldots \ldots \ldots \ldots$ A

A3.1 METHODS AND APPROACH $\ldots \ldots \ldots \ldots \ldots \ldots \ldots \ldots \ldots \ldots \ldots \ldots \ldots \ldots$

A3.2 CONTINUED SURVEILLANCE AND MAINTENANCE $\ldots \ldots \ldots \ldots$ A 8 .8

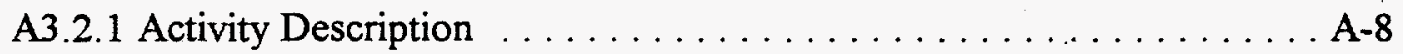

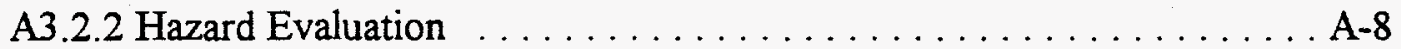

A3.3 DECONTAMINATION AND CONTINUED SURVEILLANCE AND

MAINTENANCE $\ldots \ldots \ldots \ldots \ldots \ldots \ldots \ldots \ldots \ldots \ldots \ldots \ldots \ldots \ldots \ldots \ldots$

A3.3.1 Activity Description . . . . . . . . . . . . . . . . . .

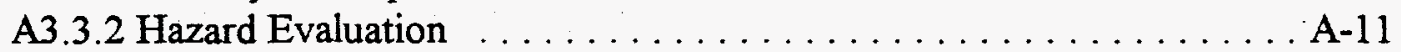

A3.4 DECONTAMINATION AND DEMOLITION $\ldots \ldots \ldots \ldots \ldots \ldots \ldots$ A-12

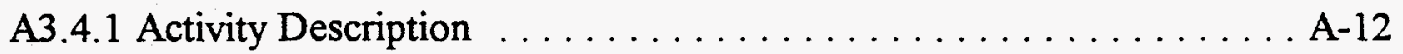

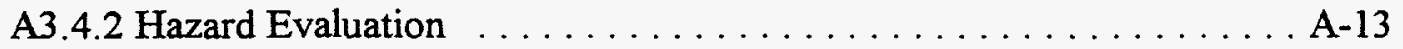

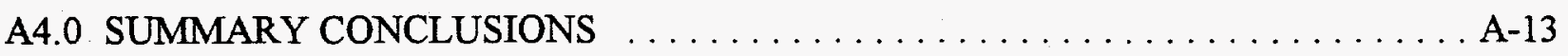

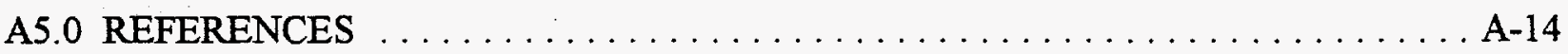

FIGURE

A-1. $233-S$ Plutonium Concentration Facility (East Elevation) $\ldots \ldots \ldots \ldots \ldots \ldots$ A-3

\section{TABLES}

A-1. 233-S Facility Process Equipment List in Use Prior to Shutdown $\ldots \ldots \ldots \ldots \ldots$ A-2

A-2. Radiological Inventory Confined in the Process Hood $\ldots \ldots \ldots \ldots \ldots \ldots \ldots \ldots \ldots$

A-3. Radiological Inventory of Surface Contamination in the Process Hood . . . . . . . . A-7 


\section{A1.0 PURPOSE AND OBJECTIVES}

Radiological hazards within the retired 233-S Plutonium Concentration Facility are the primary substances that present exposure risk. This evaluation presents a summary of the preliminary hazards assessment of the three action alternatives analyzed in the Engineering Evaluation and Cost Analysis (EE/CA) for the 233-S Plutonium Concentration Facility.

The radiological hazards that have been identified for the three alternatives are documented, and the types of prevention and mitigation requirements necessary to ensure the safety of the alternative actions are outlined. This assessment provides a basis to verify that the action alternatives pose no undue risk and for the selection of protective requirements for the detailed design and work plans. This analysis considers potential releases that could cause harm to workers, the public, and the environment.

\section{A2.0 FACILITY BACKGROUND}

\section{A2.1 FACILITY DESCRIPTION}

The process area is a four-story-high bay with $30.5-\mathrm{cm}(12-\mathrm{in}$.) thick concrete walls, and the area is divided into two zones. The two zones (the process hood and the viewing room) are separated with a partition of transparent panels and reinforced structural steel. The viewing room has open-grate flooring on each of the upper three levels, with an access ladder in the southwest corner: The process hood is $9.7 \mathrm{~m}(32 \mathrm{ft})$ high and contains a process system array with geometrically safe process vessels up to $7 \mathrm{~m}(23 \mathrm{ft})$ tall and $17.8 \mathrm{~cm}(7 \mathrm{in}$.) inside diameter. A vessel listing is provided in Table A-1, and vessel locations in the process cell are presented in Figures A-1 and A-2.

The nonprocess pipe gallery contains support lines from the Reduction Oxidation (REDOX) Plant, which enter the area through the viewing room. Equipment in the room includes instrument lines, steam lines, a chemical makeup tank (empty), and a variety of control panels. The control panels are separated from the process area by Lucite ${ }^{\mathrm{TM}}{ }^{1}$ panels that isolate the control room. The equipment room contains the necessary equipment, ducting, and wiring once used to provide and control facility make-up air. The facility water and non-process steam lines have been disconnected, and the electrical utilities have been deactivated.

\footnotetext{
${ }^{1}$ Lucite is a trade name of E.I. du Pont de Nemours \& Co.
} 
DOE/RL-96-93

Rev. 0

Table A-1. 233-S Facility Process Equipment List in Use Prior to Shutdown.

\begin{tabular}{|c|c|c|c|c|c|}
\hline ID & Name & Status ${ }^{5}$ & $\begin{array}{l}\text { Vol } \\
\text { (gals) }\end{array}$ & Dwg No. & Description \\
\hline $\mathrm{L}-1^{1}$ & Feed Tank & & 30 & $\mathrm{H}-2-45284$ & 2 ch. 10 pipe \\
\hline $\mathrm{L}-2$ & NP Concentrator ${ }^{2}$ & & 9.25 & $\mathrm{H}-2-17922$ & $\begin{array}{l}7 \text {-in. inner diameter } \times 23 \mathrm{ft} \text { high, } 44 \text { in. wide, } \\
10 \mathrm{ft} \text { of total packing }\end{array}$ \\
\hline $\mathrm{L}-3^{1}$ & Product Concentrator ${ }^{2}$ & & & $\mathrm{H}-2-30928$ & $\begin{array}{l}\text { Upper }-2(7 \text { in. } \times 8 \mathrm{ft}) \text { titanium raschig packing, } \\
\text { lower tube bundle }(6 \text { in. } \times 6 \mathrm{ft} \mathrm{sch.} 10)\end{array}$ \\
\hline$L-4^{1}$ & Product Receiver & & 14 & H-2-17929 & 2 (6 in. $\times 4.5$ in. high) pipes, sch. 10 \\
\hline$L-5^{1,3}$ & Product Filter & Unknown & 2 & H-2-39993 & $\begin{array}{l}2.5 \text { in. } x 14 \text { in. carborundum filter inside a } 6 \text { in. } \\
x 17 \text { in pipe assembly }\end{array}$ \\
\hline $\mathrm{L}-6$ & Pu Product Sampler & & 13.4 & H-2-17930 & $\begin{array}{l}3 \text { in. } x 15 \text { ft horizontal, } 5 \text { in. } \times 30 \text { in. vertical } \\
\text { sch. } 40\end{array}$ \\
\hline $\mathrm{L}-7$ & Pu PR Head Tank & Removed & 2.5 & $\mathrm{H}-2-18087$ & Pyrex $^{\mathrm{TN}^{*}}$ Glass 6 in. $\times 21$ in high \\
\hline $\mathrm{L}-8$ & NP Conc. Condenser & & 5.3 & $\mathrm{H}-2-17923$ & 7 in. $\times 4.5 \mathrm{ft}, 20$-in. wide overall \\
\hline $\mathrm{L}-9$ & Condensate Sampler & & 6 & $\mathrm{H}-2-18030$ & 8 in. $\times 40$ in. long, 30 in. wide overall sch. 40 \\
\hline $\mathrm{L}-10 \mathrm{~F}^{1}$ & L-18 Feed Tank & & 96 & $\mathrm{H}-2-17928$ & $3(6$ in $\times 22 f)$ with 2 in. $s c h 40$ risers \\
\hline $\mathrm{L}-10 \mathrm{~W}^{1}$ & L-18 Waste Tank & & 64 & H-2-17928 & $2(6$ in. $\times 22 \mathrm{ft})$ with 2 in. sch 40 risers \\
\hline$L-11^{1}$ & $\begin{array}{l}\text { Concentrator } \\
\text { Condenser }\end{array}$ & & & $\mathrm{H}-2-7252$ & 6 in. $x 6 \mathrm{ft}$ long, 5 -ft tube bundle \\
\hline $\mathrm{L}-12$ & $\begin{array}{l}\text { Pu Product } \\
\text { Concentrator }\end{array}$ & & & $\begin{array}{l}\mathrm{H}-2-30703 \\
\mathrm{H}-2-56715\end{array}$ & $\begin{array}{l}\text { Overall } 6 \text { in. } \times 22 \mathrm{ft} \mathrm{high,} \mathrm{with} 9 \mathrm{ft} \mathrm{high} \mathrm{side} \mathrm{stm} \\
\text { col, } 5 \mathrm{ft} \text { wide overall }(6 \text { in. } \times 6 \mathrm{ft} \text { sch. } 10 \text { tube } \\
\text { bundle) }\end{array}$ \\
\hline $\begin{array}{l}\mathrm{L}-12 \\
\text { mon }\end{array}$ & $\begin{array}{l}\text { Pu Product } \\
\text { Concentrator Monitor }\end{array}$ & & 1 & H-2-30911 & Same as $\mathrm{L}-18$ mon \\
\hline $\mathrm{L}-13$ & $\begin{array}{l}\text { XAF Conc. Cond. } \\
(\mathrm{Pu})\end{array}$ & & & $\mathrm{H}-2-7252$ & Same as L-11 \\
\hline $\mathrm{L}-14$ & Pu Transfer Trap & & 14 & H-2-17929 & Same as $\mathrm{L}-4$ \\
\hline $\mathrm{L}-15$ & Jet Condenser & & & $\mathrm{H}-2-7252$ & Same as L-13 \\
\hline L-16 & Pu Recycle Tk & & 18 & $\mathrm{H}-2-30820$ & 3 (6 in. $\times 56$ in. high) sch. 40 pipe \\
\hline $\begin{array}{l}\mathrm{L}-18^{\prime} \mathrm{mo} \\
\mathrm{n}\end{array}$ & $\begin{array}{l}\text { Anion IX Column } \\
\text { Monitor }\end{array}$ & & 1 & $\mathrm{H}-2-30911$ & $\begin{array}{l}6 \text { in. sch } 10 \times 9 \text { in. high w/polyethylene } \\
\text { shielding (19 in. outer diameter) same as L-12 } \\
\text { mon }\end{array}$ \\
\hline $\mathrm{L}-21$ & NP Load-out Tk & Removed & 2.2 & $\begin{array}{l}\mathrm{H}-2-30902 \\
\mathrm{H}-2-30904 \\
\end{array}$ & Pyrex ${ }^{\mathrm{TM}} 6$ in. $\mathrm{x} 18$ in. high \\
\hline $\mathrm{L}-22$ & Recycle Tk to L-16 & Removed & 5 & $\mathrm{H}-2-45287$ & Pyrex ${ }^{\mathrm{TM}} 6$ in. $\mathrm{x} 36$ in. high \\
\hline LS-1 & Vent Sump & Unknown & 3.6 & & \\
\hline \multirow[t]{2}{*}{$\mathrm{L}-1 \mathrm{~A}$} & Make-up tank & & 195 & $\mathrm{H}-2-17931$ & $3 \mathrm{ft} \times 5 \mathrm{ft}$ high overall, 1 -in. tube coil inside tank \\
\hline & Load-out Hood Sump & & $<0.1$ & H-2-18089 & 1.5 in. $\times 4$-in. deep sch. 40 load-out Hood Sump \\
\hline
\end{tabular}

1 Equipment not in use in 1964 after the fire.

2 Concentrators are titanium with 1 -in. tube bundles.

${ }^{3}$ L-5 product filter existence is uncertain but may have high dose rate; located in lower-front of process hood ( $6 \mathrm{ft}$ to left of IX column and behind viewing room floor drain position).

4 Pyrex is a trade name of Corning Glass Works.

5 Unless an exception is noted, the vessel was surveyed for inventory (BHI 1996a). 
DOE/RL-96-93

Rev. 0

Figure A-1. 233-S Plutonium Concentration Facility (East Elevation).

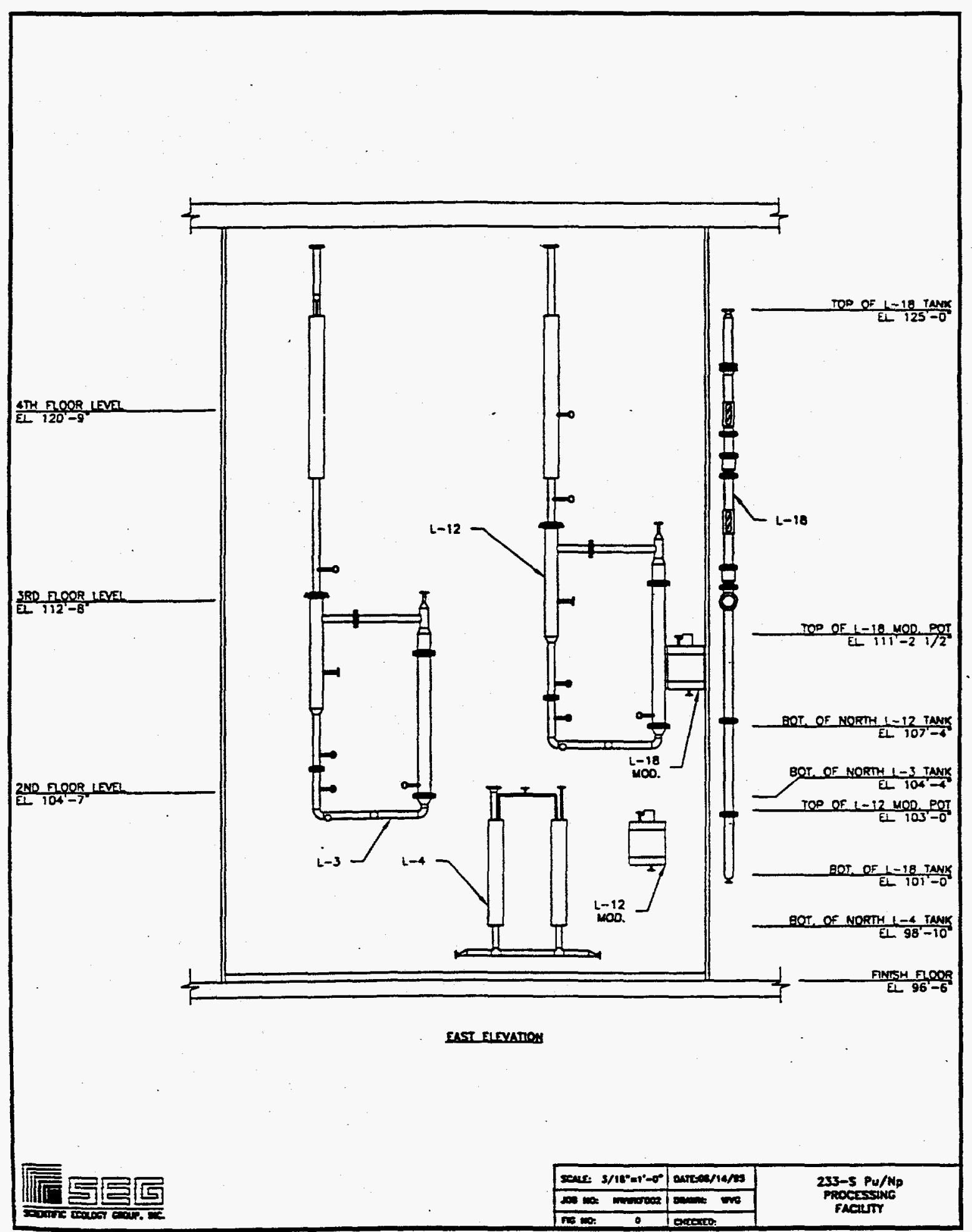


DOE/RL-96-93

Rev. 0

Figure A-2. 233-S Plutonium Concentration Facility (West Elevation).

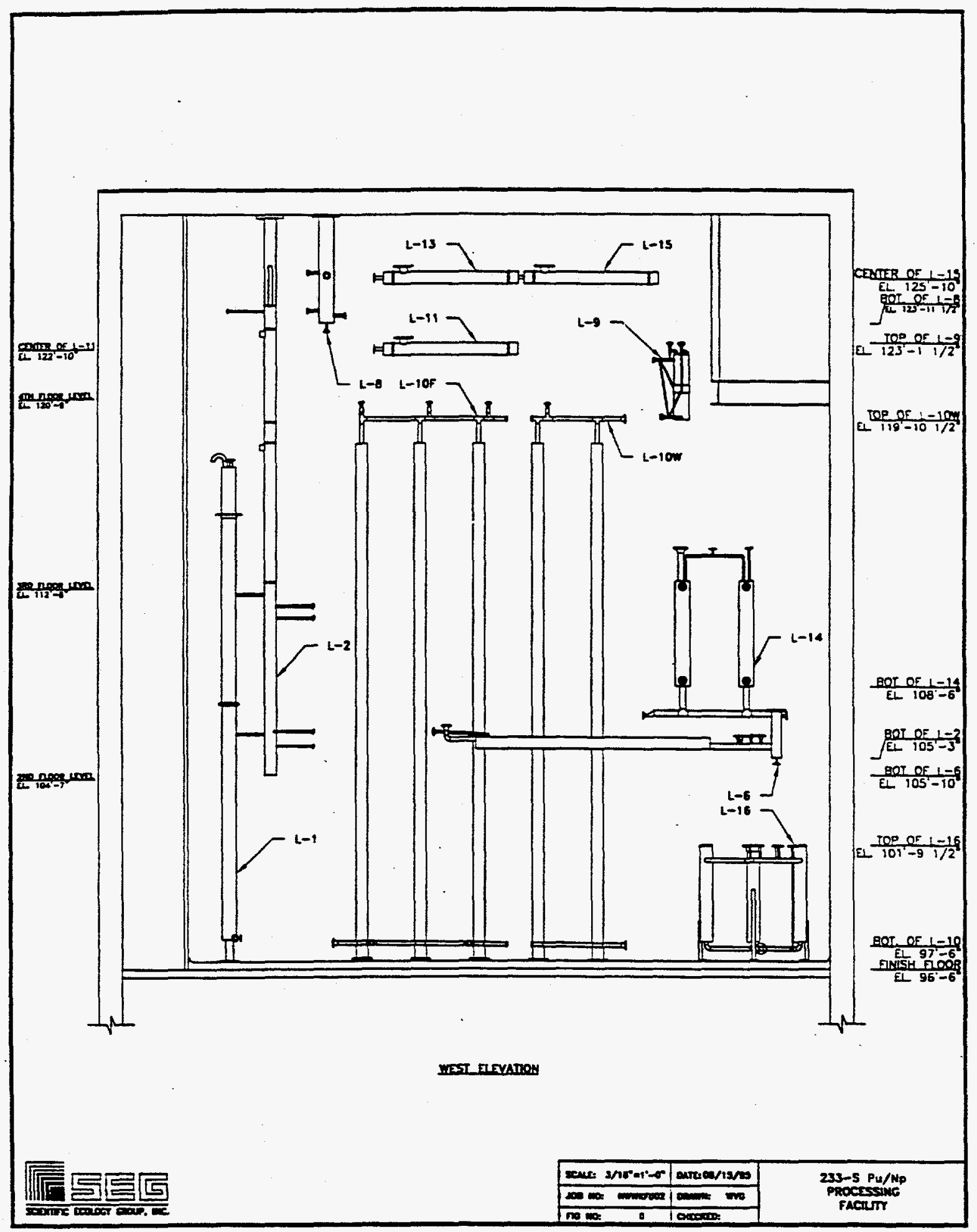


The load-out and decontamination room is located on the north side of the process hood. The load-out hood is located on the south side, or common wall with the process hood, and is a containment-type work station. The can storage rooms are located on the north side of the loadout room.

The pipe trench is a concrete subgrade structure running between the REDOX Plant and the southeast corner of the 233-S Plutonium Concentration Facility. The pipe trench is divided into two sections with cover blocks that have metal plates concealing recessed lifting bails.

A neptunium pipe trench with metal covers is located adjacent to the pipe trench.

The viewing room is adjacent to the process hood and provides access to upper levels of the process hood via three open-grating walkways along the east and south sides of the process hood enclosure. The location of the walkways divides the height of the cell into approximately equal $2.4 \mathrm{~m}(8 \mathrm{ft})$ sections. The east and south faces of the hood are constructed of Lucite ${ }^{\mathrm{TM}}$ panels that are supported by steel-frame members. There are usually two Lucite ${ }^{\mathrm{TM}}$ panels between each level, and in some cases, double panels have been installed. At the north end of the hood, a floor at the upper-levei supports the now de-energized electric and process instrumentation equipment.

The 233-SA Exhaust Filter Building is a one-story, 4.9-m (16-ft) by 7.3-m (2-4 $\mathrm{f})$ reinforced concrete structure with $15.2-\mathrm{cm}(6-$ in.) walls. The 233-SA Exhaust Filter Building is located on a 20.3-cm (8-in.) thick reinforced concrete pad at the northeast corner of the 233-S Facility. The 233-SA Exhaust Filter Building contains two parallel filter banks. Each bank has a prefilter and a series of double high-efficiency particulate air (HEPA) filters with its own exhaust fan, 7.6-m $(25-\mathrm{ft})$ high metal stack, and sampling equipment. The fans and stacks are located to the north of the building.

An abandoned filter box made of a reinforced concrete structure located below grade lies between the REDOX Plant and the 233-S Facility. The filter box is approximately $1.8 \mathrm{~m}(6 \mathrm{ft})$ wide by $1.8 \mathrm{~m}(6 \mathrm{ft})$ deep by $3.65 \mathrm{~m}(12 \mathrm{ft})$ long with $15.2-\mathrm{cm}(6-i n$.) thick walls.

\section{A2.2 INVENTORY DESCRIPTION}

\section{A2.2.1 Process Hood}

Radiological contamination exists throughout the 233-S Plutonium Concentration Facility. However, the largest sources of contamination are expected to be found in the process hood. Approximately, 1,530 grams of plutonium bearing residual is estimated to be confined in the process piping and vessels. The current estimate is based on a characterization that was completed in 1996 (BHI 1996a). An earlier documented NDA survey (WHC 1990) estimated the potential confinet inventory at approximately 950 grams of inventory in the process piping and vessels of the process hood. The 1996 estimate provides an upper-bound estimate for the confined inventory of the process hood that is used in this hazard assessment and analysis supporting the EE/CA for the 233-S Facility. Table A-2 summarizes the isotopic distribution defined in the 1996 analysis. 
DOE/RL-96-93

Rev. 0

Table A-2. Radiological Inventory Confined in the Process Hood.

\begin{tabular}{|c|c|c|}
\hline $\begin{array}{l}\text { Radiological } \\
\text { Isotope* }\end{array}$ & $\begin{array}{c}\text { Approximate } \\
\text { Quantity in Grams }\end{array}$ & $\begin{array}{c}\text { Approximate } \\
\text { Quantity in Curies }\end{array}$ \\
\hline Neptunium-237 & $6.31 E+01$ & 4.45E-02 \\
\hline Plutonium-238 & $7.04 \mathrm{E}-01$ & $1.21 \mathrm{E}+01$ \\
\hline Plutonium-239 & $1.39 E+03$ & $8.64 \mathrm{E}+01$ \\
\hline Plutonium-240 & $1.28 \mathrm{E}+02$ & $2.91 E+01$ \\
\hline Plutonium-241 & $5.19 E+00$ & $5.37 \mathrm{E}+02$ \\
\hline Plutonium-242 & $5.42 \mathrm{E}+00$ & $2.13 \mathrm{E}-02$ \\
\hline Americium-24l & $1.67 \mathrm{E}+01$ & $5.71 E+01$ \\
\hline Total & $1.61 \mathrm{E}+03$ & $7.21 \mathrm{E}+02$ \\
\hline
\end{tabular}

*Neptunium and americium inventories are conservative assumptions based on historical relationships of isotopic distributions.

As-built drawings and observations made during investigations and characterization work confirm air pathways between the process piping to the room atmosphere of the process hood. Two smear samples from the process hood indicate contamination levels of $1,000,000 \mathrm{dpm}$ and $25,000,000 \mathrm{dpm}$ alpha. The higher smear sample is from readings of a piece of tape from within the most highly contaminated area of the process hood. It is likely that some fraction of that sample was not readily dispersible but was removed because of the adhesive contained on the tape.

For purposes of scoping and planning, an estimate of interior surface area and potential surface contamination was made. The estimate assumed that all the interior surfaces are contaminated with the equivalent $25,000,000 \mathrm{dpm} / 100 \mathrm{~cm}$ smear. Using this assumption, the surface contamination in the process hood is estimated to be less than 3 grams of plutonium. An earlier analysis (DOE 1994), used in the development of a notice of construction for the State of Washington Department of Health, estimated 0.312 grams of surface contamination. However, for the purposes of this preliminary hazard assessment, the conservative estimate of 3 grams will be used. Table A-3 presents the estimated surface contamination, by isotope, within the process hood. 
DOE/RL-96-93

Rev. 0

Table A-3. Radiological Inventory of Surface Contamination in the Process Hood.

\begin{tabular}{|c|c|c|}
\hline $\begin{array}{c}\text { Radiological } \\
\text { Isotope* }\end{array}$ & $\begin{array}{c}\text { Approximate } \\
\text { Quantity in Grams }\end{array}$ & $\begin{array}{c}\text { Approximate } \\
\text { Quantity in Curies }\end{array}$ \\
\hline Neptunium-237 & $1.11 \mathrm{E}-02$ & $7.80 \mathrm{E}-05$ \\
\hline Plutonium-238 & $1.23 E-03$ & $2.11 E-02$ \\
\hline Plutonium-239 & $2.44 \mathrm{E}+00$ & $1.51 E-01$ \\
\hline Plutonium-240 & $2.24 \mathrm{E}-01$ & $5.09 \mathrm{E}-02$ \\
\hline Plutonium-241 & $9.08 \mathrm{E}-03$ & $9.40 \mathrm{E}-01$ \\
\hline Plutonium-242 & $9.48 E-03$ & $3.73 \mathrm{E}-05$ \\
\hline Americium-24l & $2.91 \mathrm{E}-02$ & $9.96 \mathrm{E}-02$ \\
\hline Total & $2.80 \mathrm{E}+00$ & $1.30 \mathrm{E}+00$ \\
\hline
\end{tabular}

*Neptunium and americium inventories are conservative assumptions based on historical relationships of isotopic distributions.

\section{A2.2.2 Other Areas}

Components in the process pipe trench, that connects 233-S Plutonium Concentration Facility and REDOX, was suspected to contain inventories of plutonium residuals. The 1996 NDA survey did not detect any appreciable inventories. However, an earlier characterization estimated that a quantity up to 350 grams of plutonium-239/240 could be confined in the piping which would be less than the detection methods used in the 1996 analysis (WHC 1990). No entry has been made into the process pipe trench; consequently, no samples have been taken nor has the surface contamination been estimated.

Other areas include the viewing room, PR can load-out room, the nonprocess pipe gallery, other nonprocess areas, the exhaust ducting, and the 233-SA Exhaust Filter Building. The 1990 estimates identify up to 8 grams of plutonium-239/240 are below layers of paint in the viewing room (WHC 1990). A fire in 1963, as well as operation of the facility, spread contamination throughout the facility. Paint was used to fixed the contamination. There are no estimates for surface contamination that may be fixed by paint in the other areas of the facility; however, it is reasonable to assume that similar conditions exist elsewhere in the facility.

The exhaust ductwork between the process hood and the 233-SA Exhaust Filter Building is estimated from assay to contain up to 2.5 grams of plutonium residual (WHC 1990). No analytical or visual characterization has been made of the residual; however, air samples from the stack indicate minimal discharges. Filter assay of the 233-SA exhaust filters indicate less than detectable quantities. There is no significant holdup of plutonium in the 233-SA Exhaust Filter Building.

Estimates in 1990 identified less than 1 gram of smearable contamination in all the nonprocess areas. The nonprocess areas of the 233-S Facility have recently been decontaminated in support 
of the recent characterization work and preparation for the removal action. Therefore, the smearable contamination in the nonprocess area is assumed to be negligible.

\section{A3.0 SUMMARY HAZARDS EVALUATION}

\section{A3.1 METHODS AND APPROACH}

A preliminary hazard assessment was prepared for the decontamination and dismantlement alternative and is documented in BHI-00892 (BHI 1996b). It was assumed that the decontamination and dismantlement alternative would address all significant hazards that could be encountered for all alternatives. Preliminary reviews of the EE/CA provided direction to address the hazards of each alternative separately. Bechtel Hanford, Inc. (BHI) project and functional staff prepared a revised hazard assessment of the action alternatives. Guidance found in the Guidelines for Hazard Evaluation Procedures (AICHE 1985) was used by the BHI staff in the evaluation and documentation of the hazard assessment. BHI (1996b) is superceded by this hazard evaluation.

\section{A3.2 CONTINUED SURVEILLANCE AND MAINTENANCE}

\section{A3.2.1 Activity Description}

Under this alternative, the existing surveillance and maintenance (S\&M) activities that are defined in BHI procedures would be continued. This involves periodic surveys of areas with potential of contamination spread and subsequent contamination release to the external environment. Surveillance is provided on a weekly basis, and the filters between areas within the building are changed on a monthly basis. Building exhaust filters are tested quarterly. Annual safety inspections are conducted to provide comparative information for tracking facility deterioration and identifying the need for changes to the planned maintenance or repairs. Mitigative actions would be provided when the threat of release is found to be unacceptable or when spread or release of contamination occurs.

\section{A3.2.2 Hazard Evaluation}

Industrial hazards of S\&M include falling, tripping, electrical shock, and asbestos exposure. In general, these hazards do not represent undue risk and are managed by implementing the worker safety and health program.

Radiation exposure to plutonium contamination is also a hazard for S\&M workers. While contamination levels have been reduced, it is reasonable to assume that the past contamination spreads will continue unless the sources are stabilized or removed. An airborne concentration in the viewing room was measured at 300 times the derived air concentration (DAC) limits during recent stabilization and characterization efforts. While levels have been reduced, it is reasonable to assume the past contamination spreads will continue unless the sources are stabilized or removed. Entry into the process hood is restricted under existing S\&M operations because the potential airborne concentrations are anticipated to exceed the protection factors of available 
personnel protective equipment. Direct radiation is a lesser exposure risk in the viewing room. Radiation levels at less than $30 \mathrm{mR} / \mathrm{h}$ have been detected in these areas. Hazard communications, worker training, radiation control procedures, and $\mathrm{S} \& \mathrm{M}$ work control procedures are required to ensure radiation safety.

Air emissions from the 233-S Plutonium Concentration Facility are a minor risk potential (DOE 1994). A HEPA exhaust ventilation system is provided to minimize environmental release and prevent contamination spread from the process hood.

Accidental criticality does not represent a significant risk during S\&M. While the total fissile inventory is estimated to exceed the subcritical mass limit, the form and distribution precludes the potential of a criticality accident during S\&M activities (BHI 1995).

Roof and other joint leaks represent a threat of water infiltration, causing contamination spread and minor worker exposure. S\&M worker training ensures the proper awareness and responsiveness to hazardous conditions.

Fire hazards do not represent an undue risk to workers or the environment. Radiological consequences (as a result of a fire) have been estimated to be minor (WHC 1994). Standard fire protection and building emergency planning are implemented for the S\&M operations.

Natural phenomena hazards of high wind and earthquake pose no undue risk to the S\&M operations or to the confinement structures. The structures, though likely built to the 1952 edition of the Uniform Building Code (UBC), are judged to withstand current UBC loads without catastrophic failure. Site specific snow and ash loads also do not present an undue risk to the 233-S Facility. Infiltration of moisture and winter freeze and thaw cycles are a threat to the confinement structures of the building. S\&M procedures, reactive maintenance, and a building emergency plan provide the protective requirements for relevant natural phenomena hazards.

\section{A3.3 DECONTAMINATION AND CONTINUED SURVEILLANCE AND MAINTENANCE}

\section{A3.3.1 Activity Description}

The scope of decontamination and continued S\&M includes the following:

- Decontamination/stabilization of the high surface contamination of the process hood and process pipe trench

- Removal of the fissile inventories in the process hood and process pipe trench

- Decontamination/stabilization of the remaining building surfaces

- Shut down of the building exhaust system

- Disposal of the decontamination wastes 
Work planning has addressed the pipe gallery activities to include the removal of asbestos-wrapped steam lines and insulated raw water lines, process air lines, and instrument lines. The control panels and chemical makeup tank will be removed from the walls, floors, and ceilings.

Prior to the decontamination and decommissioning of the load-out hood, a confinement enclosure will be established around the entire hood. Air flow within this enclosure will be directed to the hood exhaust and if necessary, HEPA-filtered blower system will be attached to the enclosure to provide the air flow controls. Initial in-hood operations will include surface vacuuming or absorbent wiping of the internal hood surfaces. Then the surfaces will be coated with a fixative readying the hood for dismantlement. Powered hand tools will be used to section the hood into appropriate pieces. After the entire hood has been removed, the exhaust ducting will be modified to minimize the spread of airborne contaminants. Removal of the confinement enclosure will be completed by wiping the inner layer with absorbent wipes and then removing the inner layer. A fixative coating may also be applied to the inner layer if necessary and then the remainder of the enclosure will be disassembled.

Removal of the pipes in the process pipe trench will be performed to eliminate sources of contamination and to reduce the radioactive material inventory of the facility.

Equipment dismantlement in the process hood will require installation of an in-cell rigging system, modification or adjustments of the ventilation system, and in-hood preparatory cleaning. Cleaning will be achieved by scooping or vacuuming techniques. Following the hood cleaning operations, the equipment systems in the process hood will be vented and drained of remaining liquids and cut into sections in place. (The process piping was drained and isolated as part of facility deactivation. The planned draining activity is precautionary, no free liquid is anticipated.)

It is anticipated that the equipment removal will progress from the lower levels of the process hood to the upper levels. Lowering of sectioned equipment to the lower level will be carefully performed and removing sectioned segments will be pre-planned so hang up and excessive handling is not required. Once each segment has been lowered to the ground-floor level, the segments will be removed to the waste packaging support enclosure. Existing unistruts and pad-eyes embedded into the roof will be used as rigging points, as they were initially used to hoist the equipment into place during construction. Engineering evaluations of these lifting points will be conducted to verify their condition prior to their use. An I-beam roof support over the upper walkway also exists that can be used to support equipment removal from that level. Tie-off or bracing of the system segments as they are cut will be accomplished from overhead rigging (previously installed) or from localized structures adapted for this purpose.

Once the building equipment has been removed, the interior ductwork will be readied for dismantlement. This effort will involve installing sealed caps on all ducting at the wall or ceiling surfaces where they enter the rooms. Where the ductwork extends into rooms, hallways or overheads, those sections will be cut and removed. The interior ductwork contained in the facility's walls and ceilings will have fixative applied prior to their removal during building dismantlement. 
At this point of the project, additional decontamination of the walls, ceilings, and floors will be performed to minimize the opportunity for contamination spread during the continued S\&M. A decision to remove or stabilize the floor drainage system will be made.

Once the building interiors have been decontaminated or stabilized to a predetermined end point, preparations to turn off and isolate the exhaust ventilation system will begin. The inner surfaces of the exterior exhaust duct will be coated with a contaminant fixant to stabilize these surfaces The exhaust fans will be turned off but will be maintained for possible future use.

Verification of achieving the predetermined decontamination or stabilization criteria will precede implementation of reduced S\&M requirements. The facility $S \& M$ plan and procedures will be revised, and the personnel training to support the revised S\&M program for the isolated 233-S Plutonium Concentration Facility.

\section{A3.3.2 Hazard Evaluation}

This alternative requires workers to enter into areas that are currently restricted because of potential radiological exposures. This alternative provides a higher potential to accidentally cause a radiological relsase. However, no undue risk is identified either to workers or the environment.

Industrial hazards of S\&M will be present during the decontamination phase. The hazard of being struck by hazards that are not significant in current S\&M activities (WHC 1993) would be present with the materials handling required by decontamination and waste handling. The opportunity for industrial accidents will increase during the period of decontamination.

The risk of radiation exposure is greater for this alternative than for continued S\&M. The radiological exposure risks for this alternative include, but are not limited to, risks associated with the continued S\&M alternative. The majority of decontamination work will be in potentially high airborne areas of the process hood and process pipe trench. In these areas, especially in the process hood, existing surface contamination is anticipated to exceed the protection factors of self-contained breathing apparatus (SCBA). Radiation safety requirements will define an adequate level of surface stabilization prior to manned entry of the process hood. The exhaust ventilation system would likely require special technical and administrative controls. A workspecific health and safety plan (HASP) and radiation work permits will define the appropriate worker controls.

Disassembly and removal of the piping systems creates an additional risk of release. Exhaust ventilation is required to prevent the spread of contamination to areas outside the process hood and to prevent undue discharges to the environment. Building/site emergency planning will be required to mitigate the unlikely release of radioactive contamination.

Radioactive gas generation from decay could present an inhalation or explosive hazard portions of the piping and vessel systems. While it is not anticipated that the process piping is a closed system, the condition has not be verified. Further analysis to support the RDR will be required to define. Additionally, this hazard would likely be addressed in the building emergency plan. Disposal of gas-generating substances will be addressed by requirements for packaging, shipping, and waste acceptance. 
The characterization performed for the process hood (BHI 1996a) and process pipe trench (WHC 1990) identified there was sufficient quantity of fissile material to require a criticality analysis. A preliminary analysis by Los Alamos Technical Associates (BHI 1996c) and a separate verification (BHI 1996d) documented that an accidental criticality is highly unlikely. However, uncertainties regarding inventory estimates require special administrative work controls to prevent any chance of accidental criticality. Special administrative controls will be prepared for the dismantling, handling, and verifying inventory (NDA) for the process piping and vessels. Specialized equipment, such as critically safe vacuums and waste containers, will be required during operations.

Risk of radiation exposure to workers at 233-S Plutonium Concentration Facility, other onsite workers and the local environment are associated with packaging, staging, and transporting the waste for disposal or retrievable storage. The U.S. Department of Transportation (DOT) and U.S. Department of Energy (DOE) standards would be used to define the protective requirements necessary for the safe handling of the contaminated wastes. Waste acceptance criteria of the Environmental Restoration Disposal Facility (ERDF) would be requirements applicable for low level and mixed waste. Applicable onsite standards and requirements would define the appropriate requirements for transuranic waste.

Natural phenomena hazards are of similar consequence as the alternative for continued S\&M with one exception. There is a remote possibility that an earthquake could occur during decontamination and removal of the process piping and vessels. A release could result in airborne contamination that would exceed the protection levels of the personal protective equipment. Confinement systems, such as temporary green housing, special wrapping, and remote-handling work procedures would be required. Building/site emergency preparedness procedures would be required.

\section{A3.4 DECONTAMINATION AND DEMOLITION}

\section{A3.4.1 Activity Description}

The decontamination and demolition alternative would involve all of the decontamination operations as described in the decontamination and continued S\&M alternative. Additionally, this alternative would dismantle the remaining decontaminated or stabilized structures and dispose of them at the ERDF. After decontamination activities have been completed within the 233-S and 233-SA facilities, final dismantlement efforts will proceed.

Dismantlement would be accomplished by carefully sectioning the structure using procedures to minimize the threat of airborne contamination. The sections would be packaged to meet predetermined criteria for transportation to the ERDF. Dismantlement would likely begin at the top of the 233-S Plutonium Finishing Facility. Dismantlement techniques would be designed to allow noncontaminated building materials to be recycled where possible.

Once the facilities have been dismantled, the floor slab footers, filter box, and pipe trench will be removed. A decision regarding when to remove the floor drainage system will be made considering two options: (1) removal prior to building dismantlement or (2) removal after the building is removed. These locations will have been decontaminated using the same methods used 
DOE/RL-96-93

Rev. 0

for the 233-S and 233-SA facilities. After a final survey of the 233-S Plutonium Finishing Facility decontamination and decommissioning site has been performed and any residual contaminants are removed or adequately isolated, the project will be complete.

Surface area remaining after demolition and disposal would be stabilized to minimize the spread of detectable residual contamination. Stabilization methods may include providing a clean soil cover or other appropriate engineered barriers. Minimal administrative or institutional controls may be required, depending on residual inventories remaining in the shallow surface soils.

\section{A3.4.2 Hazard Evaluation}

No undue risk is anticipated from the hazards of this alternative. The hazards associated with the decontamination and dismantlement alternative are the same as those for the decontamination and continued S\&M alternative. The primary difference is industrial hazards present a greater risk due to the overhead hazards, general handling and transport of the dismantled facility sections. The potential exists to encounter buried utilities or unknown structures during subsurface activities. These hazards would be controlled by worker safety requirements and compliance with site excavation permits and site emergency plans.

Removal of the subgrade structures would introduce the risk of exposure to below grade contamination. Standard contamination controls would be required for work procedures and site emergency planning.

\section{A4.0 SUMMARY CONCLUSIONS}

Plutonium contamination is the hazardous substance of concern in the 233-S Plutonium Finishing Facility. Contamination spread is a characteristic of the history of the building since it has been a surplus facility. Migration of the plutonium contamination has been found on the outside of the facility and has required decontamination and stabilization is past years. It is reasonable to assume that because of the inherent nature to emit particles, contamination will continue a slow migration until the residual inventory is removed and safely disposed. The quantity of residual plutonium, the dispersible nature of the material, and the fissile potential are characteristics of a hazard category 2, nuclear facility (DOE 1992a and DOE 1992b).

The hazard associated with the three removal alternatives can be controlled using known and previously demonstrated procedures and technologies. During the remedial design phase, detailed work plans will be developed based on the suspected and known hazards related to the 233-S Plutonium Concentration Facility and the selected removal action. Safety and health requirements that are identified in the text of this EE/CA and subsequent action memorandum will be implemented in the plans and procedures of the remedial design report and subsequent work procedures. Programmatic safety and health requirements will be provided by compliance with appropriate BHI procedures and management system. The combination of specific requirements implemented from the selected ARARs and standards to be considered and the BHI safety management system will ensure that no undue risk is incurred in the selected removal action. 
DOE/RL-96-93

Rev. 0

\section{A5.0 REFERENCES}

AICHE, 1985, Guidelines for Hazard Evaluation Procedures, American Institute of Chemical Engineers, New York, New York.

BHI, 1995, Bechtel Hanford, Inc. Implementation Plan for U.S. Department of Energy Order 5480.24, BHI-00283, Rev. 01, Bechtel Hanford, Inc., Richland, Washington.

BHI, 1996a, Passive Neutron Survey of the 233-S Plutonium Concentration Facility, BHI-00749, Rev. 0, Bechtel Hanford, Inc., Richland, Washington.

BHI, 1996b, Safety Analysis for the 233-S Decontamination and Decommissioning Project, BHI-00892, Rev. 0, Bechtel Hanford, Inc., Richland, Washington.

BHI, 1996c, Criticality Evaluation for the 233-S Decontamination and Decommissioning Project, BHI-00891, Rev.. 0, Bechtel Hanford, Inc., Richland, Washington.

BHI, 1996d, Plutonium Concentration System Removal Criticality Review, Calculation No. 0200W-CA-N0001, Rev. 0, Bechtel Hanford, Inc., Richland, Washington.

DOE, 1992a, Nuclear Safety Analysis Reports, DOE Order 5480.23, U. S. Department of Energy, Washington, D.C.

DOE, 1992b, Hazard Categorization and Accident Analysis Techniques for Compliance with DOE Orcler 5480.23, Nuclear Safety Analysis Reports, DOE-STD-1027-92, U. S. Department of Energy, Washington, D.C.

DOE, 1994, Radioactive Air Emissions Programs, Notice of Construction for the Decommissioning of the 233-S Plutonium Concentration Facility Complex, DOE/RL-94-107, U.S. Department of Energy, Richland Operations Office, Richland, Washington.

WHC, 1990, Radiological Characterization of the 233-S Facility, WHC-SD-CP-TI-163, Rev. 0, Westinghouse Hanford Company, Richland, Washington.

WHC, 1994, Fire Hazards Analysis for the Plutonium Concentration Facility, Building 233-S, WHC-SD-DD-FHA-001, Rev. 1, Westinghouse Hanford Company, Richland, Washington. 
Rev. 0

Number of Copies

\section{ONSITE}

21

U.S. Department of Energy

Richland Operations Office

J. M. Bruggeman (20)

H0-12

DOE/RL Public Reading Room

H2-53

27

ERC Team

J. H. Dunkirk

$\mathrm{H} 0-13$

P. K. Jackson

X5-53

N. R. Kerr

$\mathrm{H} 0-18$

R. J. Landon

$\mathrm{H} 0-18$

J. J. McGuire

$\mathrm{X} 5-53$

M. A. Mihalic

$\mathrm{X} 5-53$

J. E. Rugg (5)

$\times 5-53$

S. D. Thoren

$\mathrm{X} 5-53$

AR File (9)

H0-09

D\&D Project Files

X5-53

Document and Information Services (4)

$\mathrm{H} 0-09$

PNNL Technical Library

P8-55 